\title{
Gjermundbufunnet - en småkonges grav med østlig tilsnitt på Ringerike
}

\begin{abstract}
The Gjermundbu find came to light under difficult, wartime circumstances in 1943. With travel and other restrictions in place, a full-scale rescue excavation was not possible, and the find is poorly documented. What is certain, is that we are dealing with a very rich grave from the end of the $10^{\text {th }}$ century, with few if any parallels outside the milieu of the large ship graves. The cremation grave held some very uncommon objects, like a helmet and a chain mail, as well as five or six horses and one or two sledges. While there are many similarities between the Gjermundbu find and the Vendel and Valsgärde burials in Sweden, the closest parallels to the find are the so-called druzhina burials in present-day Russia and Ukraine, and the authors suggest that the buried man was a petty king, who had served in the retinue of Vladimir the Great or one of his predecessors, together with other warriors from Ringerike.
\end{abstract}

Gjermundbufunnet har en helt egen klang i nordisk og europeisk vikingtidsarkeologi, takket være hjelmen og brynjeveven som funnet inneholder. Men nettopp disse to gjenstandene har langt på vei overskygget funnet som sådan, og det har i svært liten grad blitt tatt opp til videre behandling og analyse etter at det ble presentert for første gang av Sigurd Grieg i 1947 (Grieg 1947). På grunn av de spesielle funnomstendighetene er originaldokumentasjonen dessuten mangelfull. I det følgende vil vi se nærmere på den spesielle gravskikken og på noen av gjenstandene i funnet og forsøke å gi et mer helhetlig bilde av Gjermundbugraven i lokal, regional og overregional kontekst. ${ }^{1}$

\section{Et museum i krig}

På selveste 17. mai 1943 satte konservator Sverre Marstrander punktum for sin innberetning nummer to om et stort gravfunn på gården Gjermundbu i Haugsbygd på Ringerike (Marstrander 1943c). A.W. Brøgger har satt sin signatur og datoen 24/5-43 på forsiden av innberetningen, som tegn på at den var lest og godkjent. Det var krig i Norge, og Universitetets oldsaksamling var ikke uberørt av begivenhetene hjemme og ute. Brøgger var i egenskap av samlingens bestyrer blitt arrestert i september 1941, i forbindelse med aksjonen mot universitetet, sammen med underbestyrer Grieg. Brøgger satt 13 måneder på Grini fangeleir frem til slutten av oktober 1942. Grieg ble arrestert på nytt våren 1944 og internert frem til krigens slutt. Noen måneder før hadde Marstrander rømt til Sverige etter at han hadde 


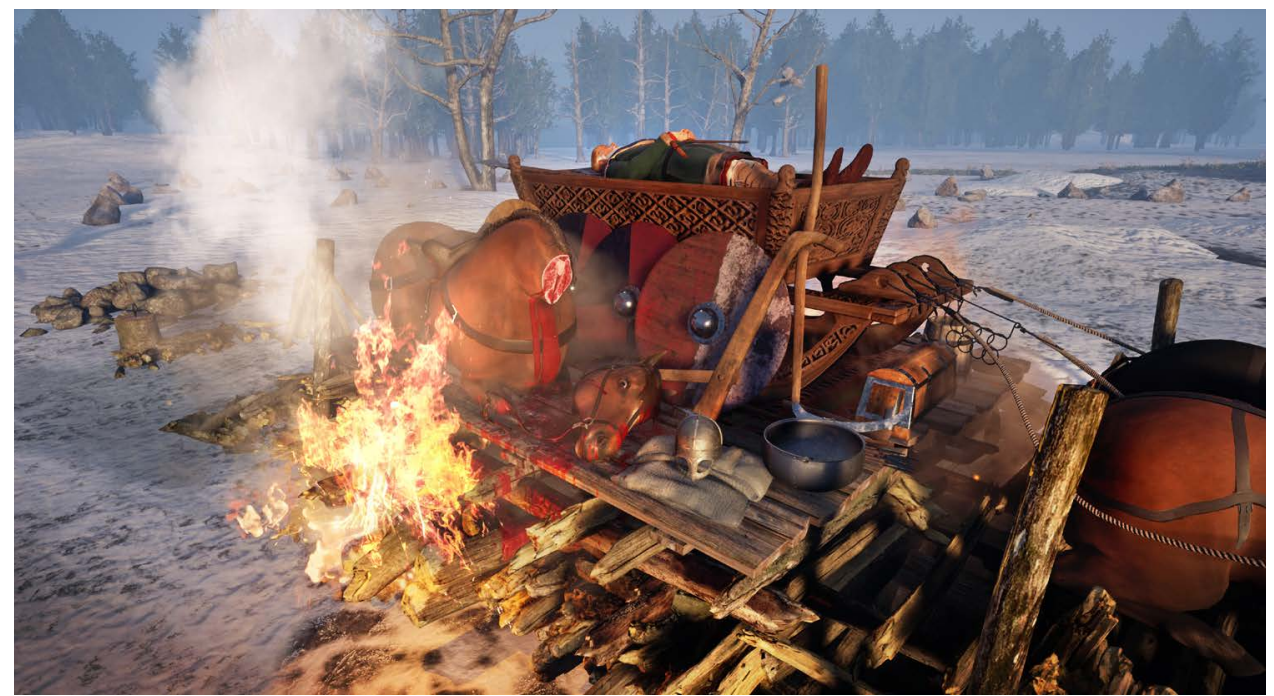

Figur 1. Forslag til rekonstruksjon av likbrenningssituasjonen på Gjermundbu. Illustrasjon: Ragnar L. Børsheim.

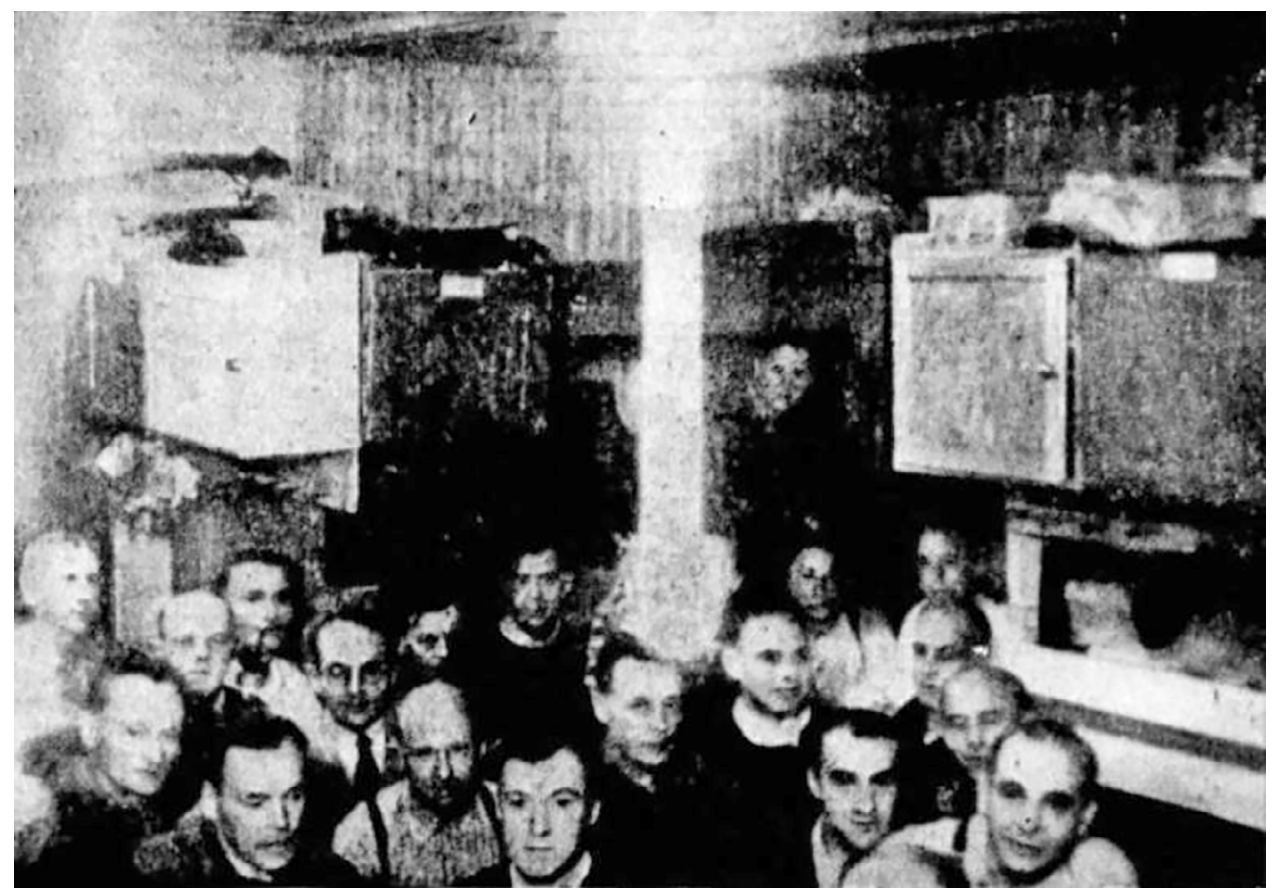

Figur 2. Julekveld på Grini 1944. Sigurd Grieg til høyre, bak. Etter Aftenposten, 24. desember 1945. 
sluppet ut fra Grini (Blindheim 1985:34). Wenke Slomann måtte også søke tilflukt i Sverige (Blindheim 1985:34).

Oldsaksamlingen fikk lov til å fortsette driften fordi institusjonen hadde forvaltningsmessige oppgaver, men reisevirksomheten var blitt kraftig redusert (Hagen 1997:205, jf. Hougen 1951). Bygningen som huset museet, ble beslaglagt til bruk for Organisation Todt i mai 1942 (Blindheim 1985:34). Etter hvert som stadig flere av museets vitenskapelig ansatte ble borte, ble det lagt et stort ansvar på de yngre som var igjen, ikke minst på Marstrander (født 1910), men også på studentene Charlotte Thomas (Blindheim, født 1917) og Erik Hinsch (født 1925). Derfor ble det disse tre som fikk ansvaret for å hente inn og dokumentere to store vikingtidsfunn som kom for dagen i løpet av krigen, Bygglandsfunnet (1944, se Stylegar 2014) og Gjermundbufunnet (1943). Begge funn skulle komme til å spille en viktig rolle i senere forskning. Med Marstrander ute av bildet, ble det Grieg som fikk ansvaret for publiseringen av det store funnet fra Gjermundbu. Han rakk å fullføre manuskriptet i løpet av vinteren 1943/44, før han igjen ble internert (Hagen 1997:205). De aktive krigshandlingene i Norge var over på det tidspunkt da Brøgger sendte Marstrander og Blindheim til Gjermundbu, i april 1943. Men i aprildagene tre år tidligere hadde noen av de verste kampene under felttoget i Sør-Norge foregått nettopp i Haugsbygd, og på jordene nedenfor funnstedet på Gjermundbu skjedde noen av de hardeste trefningene.

\section{Funnomstendighetene}

Våren 1943 var Gunnar Gjermundbo i gang med å bygge kårbolig for sine foreldre, Lars og Elise Gjermundbo. De hadde sett seg ut en tomt på Vesleenga, en liten høyde i utkanten av gården, nær grensen mot nabogården Bølgen. På stedet lå en stor gravhaug som Gunnar godt kjente til, men den hadde han ikke tenkt å røre. Like vest for gravhaugen lå det en langaktig forhøyning som nå måtte ryddes vekk for å få plass til byggetomt og frukthage. Det var da han begynte å grave i denne forhøyningen, som viste seg å bestå av svart jord og større steiner, at de første gjenstandene dukket opp. Det skjedde om ettermiddagen 29. mars, og dagen etter fikk Oldsaksamlingen telefonisk melding om funnet fra lokalhistoriker Jon Guldal.

31. mars brakte Ringerikes Blad nyheten om funnet. Avisen kunne fortelle at man hadde støtt på «jernsaker», og at det var plukket opp mer enn 30 ulike gjenstander, deriblant to økser, en ringbrynje, et «slagsverd», fire munnbitt, terninger, to «hvite kuler», «briller» til en hjelm, spyd, kniv og mange «småsaker», foruten en jernplate med «skjønne forsiringer». Lars Gjermundbo ble intervjuet i sakens anledning (Ringerikes Blad 31. mars 1943).

Gjenstandene ble tatt med hjem til Lars Gjermundbo etter hvert som de kom for dagen. Der ble de plassert i storstua, og kom til å dekke halve gulvet (Ringerikes Blad 2. april 1943). Lokalavisen var på besøk på Gjermundbu 1. april og så på funnene hjemme hos Lars. Nå nevnes også en stor jernkjel som hadde ligget hvelvet over gravgodset, «forskjellige spydspisser», «en hel del» pilspisser og kniver, deler av hjelmen og «forskjellige beslag og spenner». Om de funne øksene heter det at de er «vakkert forsirte». Antallet munnbitt har ellers økt til fem, og det nevnes en lenke «til seletøyet». Avisen hadde dessuten vært i kontakt med Marstrander i Oslo, som kunne meddele at «både funnomstendighetene og sammensetningen av gravgodset peker i retning av en høvdinggrav» fra vikingtiden. Marstrander 


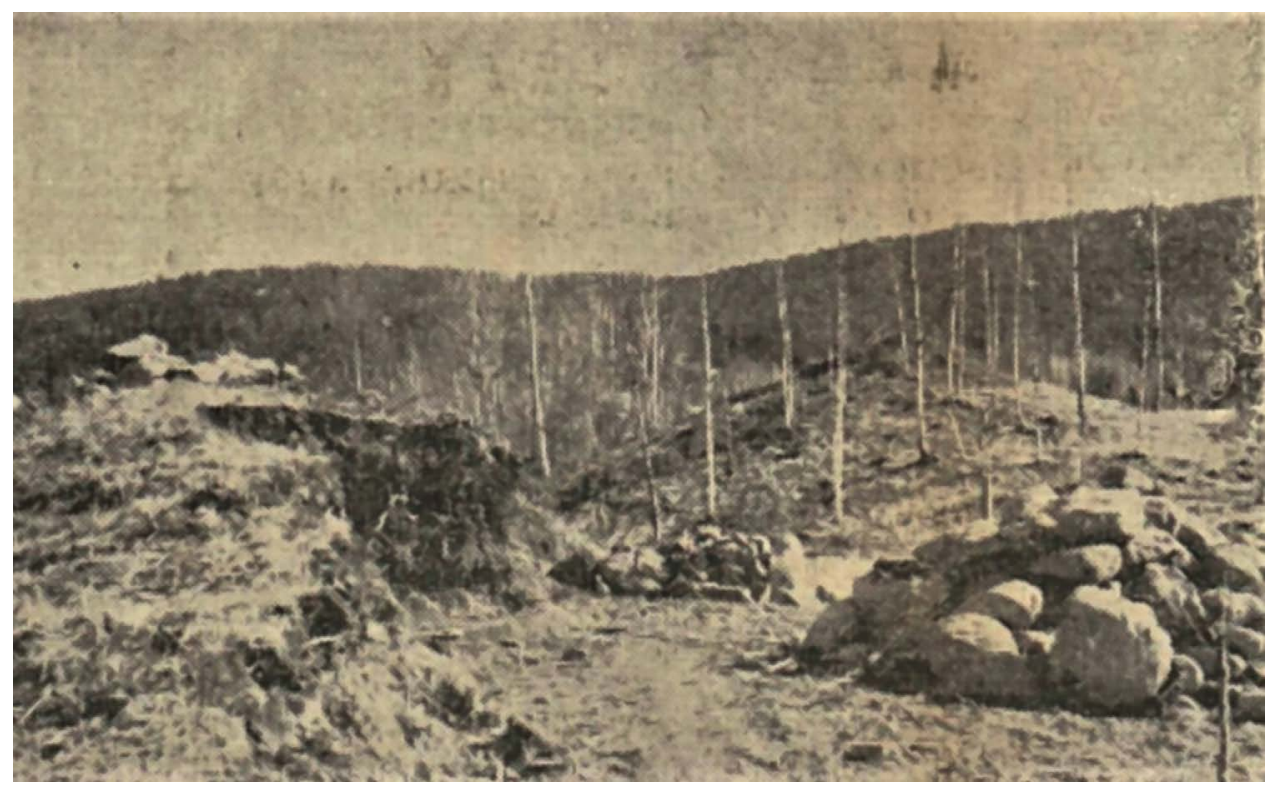

Figur 3. Fotografi tatt 1. april 1943; restene av den skipsformede haugen til venstre $i$ forgrunnen, storhaugen i bakgrunnen. Foto mot øst. Etter Ringerikes Blad, 2. april 1943.

opplyste også at museet samme dag ville sende «frk. Thomas» og Jon Guldal til Haugsbygd for å undersøke funnet nærmere (Ringerikes Blad 2. april 1943).

I mellomtiden hadde Brøgger bestemt at det skulle gjøres en etterundersøkelse, og Marstrander og Blindheim ankom Gjermundbu 2. april (Grieg 1947:1). Med i følget var også Jon Guldal, som deltok i ettergravingen (Guldal 1943, 1953).

\section{Etterundersøkelsene i 1943}

Samme dag ble gravhaugen målt opp, og man gikk igjennom de oppgravde massene nærmest stedet der gjenstandene var kommet for dagen. Etterundersøkelsen kan ikke ha tatt særlig lang tid; i løpet av denne ene dagen var det nemlig også tid til «en herlig middag med kjøttkaker, som den gang var en sjelden kost for mange», hjemme hos Elise og Lars (Guldal 1953). Store deler av haugen var på det tidspunktet fjernet, men originaldokumentasjonen viser at det dreide seg om en spissoval, nærmest skipsformet, langhaug.

I den endelige rapporten (Marstrander 1943a), i museets tilvekst og hos Grieg (1947:1) er målene oppgitt til $25 \times 8 \mathrm{~m}$, men originaltegningene tyder på at haugens lengde var noe større, inntil $29 \mathrm{~m}$, og bredden ser ut til å ha vært ca. $9 \mathrm{~m}$. Høyden var 1,8 m på midten. Langhaugen var orientert øst-vest, og den østlige enden befant seg 5-6 m fra den nevnte monumentale gravhaugen i Vesleenga (Ringerikes Blad, 2. april 1943). Haugen bestod delvis av «skalljord» (forvitringsjord), som grunnen ellers i området.

Omtrent midt $\mathrm{i}$ langhaugen hadde Gunnar Gjermundbo støtt på et nokså tett lag av større stein; det fantes stein også utenfor sentrum, men mer spredt. Under steinlaget lå et lag med 


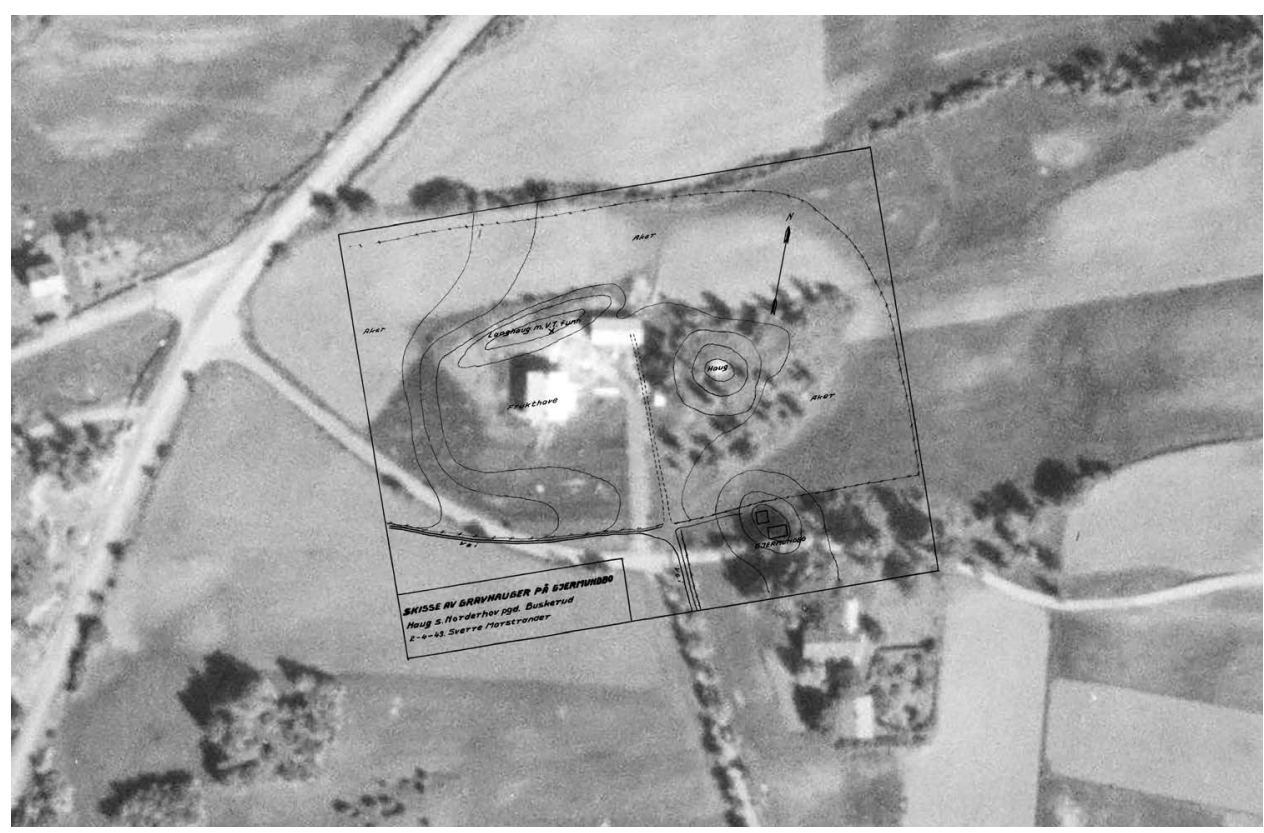

Figur 4. Marstranders ikke-målsatte situasjonsskisse fra Gjermundbu i april 1943, forsøksvis plassert over flyfoto fra 1947. Illustrasjonen gir et inntrykk av den skipsformede gravhaugen og forholdet til den - antatt - eldre storhaugen. Illustrasjon: Ragnar L. Børsheim.

kull og under dette, ca. $1 \mathrm{~m}$ under haugens overflate, lå det meste av brynjeveven brettet sammen «i et flak». Mer brynjevev lå for seg selv ved siden av en stor jernkjel, som var hvelvet over de øvrige gjenstandene. De sistnevnte lå tett sammenpakket, bare enkelte av de lengre gjenstandene, som sverdklingen og spydspissene, stakk ut på siden. I det følgende refererer vi til denne strukturen som deponering 1 .

Ettergravingen på funnstedet gav ikke nye gjenstandsfunn, ifølge innberetningen (Marstrander 1943a). Men Jon Guldal fortalte at han fant en fragmentarisk terning av bein, som imidlertid var så skjør at den smuldret bort mellom fingrene hans (Guldal 1943). Det ble ellers avdekket et ca. $40 \mathrm{~cm}$ tykt lag med kull iblandet brente bein like ved gropen der kjelen og oldsakene hadde ligget. Vi refererer videre til denne strukturen som deponering 2.

Hovedhensikten med reisen til Ringerike var først og fremst å sikre de gjenstandene som alt var funnet. Da Aftenposten besøkte museet 9. april, var det liten tvil om at Marstrander og hans kolleger for alvor hadde tatt inn over seg at det dreide seg om et høyst usedvanlig funn. Avisen ble invitert med ned i kjelleren av en konservator som var «full av begeistring», og der nede lå gjenstandene klare til konservering.

Marstrander viste frem og fortalte om doppskoen til sverdet, som han ut fra stilen mente daterte funnet til slutten av 900-årene. Selvsagt trakk han også frem brynjeveven og hjelmen, som ikke var kjent fra andre gravfunn, og han viste hvordan det nederst på hjelmen var spor etter en brynjehette som har dekket nakke og skuldre. Om sverdet kunne han fortelle at det var av en type fra samme tid som doppskoen. 


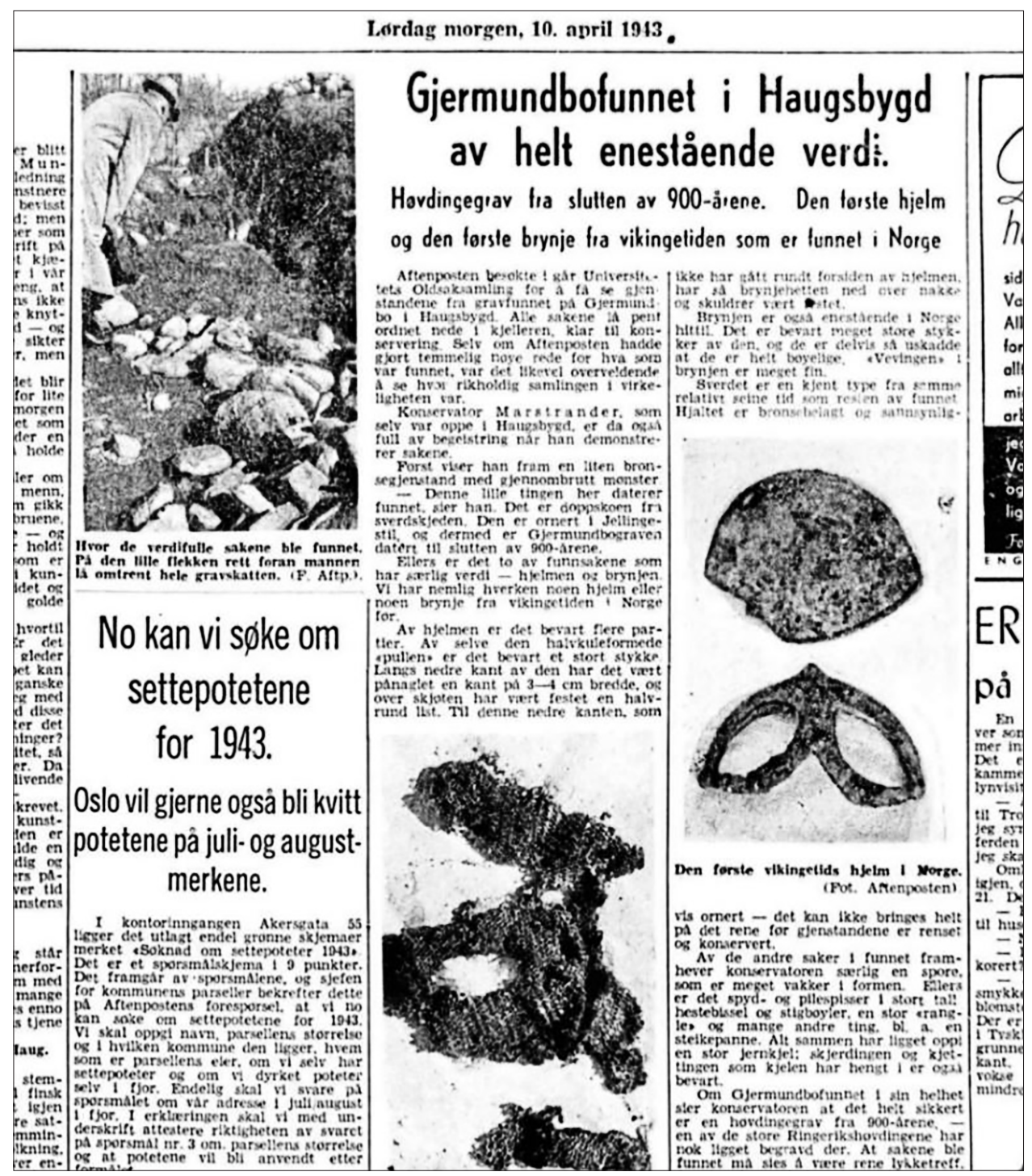

Figur 5. Aftenpostens oppslag om det store funnet på Gjermundbu, 10. april 1943.

Ellers var han opptatt av et par sporer, som han mente var «meget vakre» i formen. Av det store gravinventaret forøvrig, nevner artikkelen «spyd- og pilespisser i stort tall, hestebissel og stigbøyler, en stor rangle og mange andre ting, bl.a. en steikepanne. Alt sammen har ligget oppi en stor jernkjel; skjerdingen og kjettingen som kjelen har hengt i, er også bevart». Den usikkerheten som eventuelt måtte ha rådet omkring funnets status, var det ikke lenger spor av: Gjermundbugraven var nå «helt sikkert (...) en høvdinggrav fra 900-årene», og haugen bygd over «en av de store Ringerikshøvdinger» (Aftenposten 10. april 1943). 


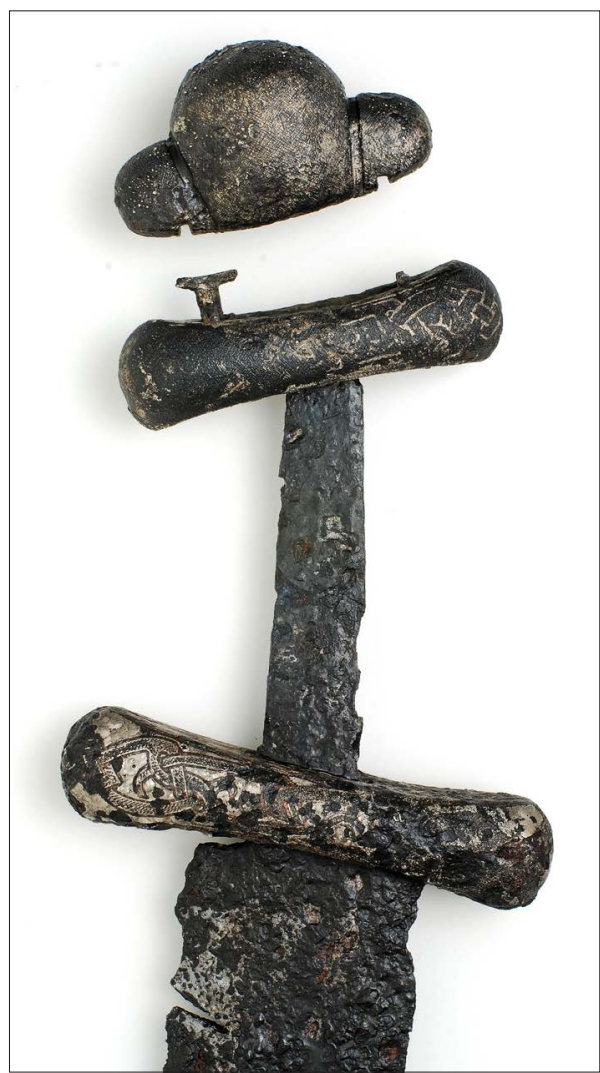

Figur 6. S-sverdet fra Gjermundbu. Foto:

Vegard Vike/Kulturhistorisk museum, UiO.

CC BY-SA 4.0

Om ettermiddagen 2. april hadde Marstrander og Blindheim reist tilbake til Oslo; de regnet ikke med at det var mer å finne i haugen (Marstrander 1943a). Ti dager senere fikk Lars Gjermundbo et brev fra Marstrander på vegne av Oldsaksamlingen; museet hadde besluttet å tildele ham en godtgjørelse på 250 kroner, og gav ellers tillatelse til å fjerne resten av langhaugen. Hva den store, gjenværende gravhaugen angikk, ble det påpekt at den er «et sjeldent vakkert fortidsminne og en pryd for egnen», og museet ba om at den kunne få ligge urørt (Marstrander 1943b).

Neste akt startet 1. mai, i form av et brev fra den respekterte bygdemannen og tidligere læreren Johan Skøien til museet. Det var kommet for dagen flere gjenstander, skrev han, deriblant noen av bronse. Hva verre var, han hadde hørt fra «pålitelig hold» at flere gjenstander var forsøkt solgt (Skøien 1943). Brøgger sendte så 4. mai en anmeldelse til det lokale politiet, men uten å oppgi navnet på informanten (Brøgger 1943). Deretter fulgte avhør av folkene på Gjermundbu 8. mai, men ingen ytterligere kontakt med Skøien.

I avhørene kom det frem at det riktignok var blitt funnet flere gjenstander i gravhaugen da tomtearbeidet startet opp igjen noen dager etter at Marstrander og Blindheim hadde avsluttet sin etterundersøkelse, men at ingenting var blitt solgt eller forsøkt solgt. Både Lars og Gunnar Gjermundbo forklarte at det de hadde funnet - et sverd, en øks og flere andre ting - var tatt $i$ hus, og at ingen hadde fătt se sakene uten at noen fra familien var til stede. Gunnar kunne opplyse at han visste det hadde vært folk på utgravningsstedet «for å finne ting», men trodde ikke at noen hadde funnet noe; han hadde ellers passet på å ta med graveredskapene hjem hver kveld. Lars la til at han foreløpig ikke hadde meldt fra til museet om de nye funnene, men at planen var å reise inn til Oslo med gjenstandene (Grylling 1943). Med det avsluttet politiet etterforskningen.

Politirapporten ble sendt til Oldsaksamlingen 10. mai, og 14. mai var Marstrander på plass på Gjermundbu igjen. I hans innberetning om de nye gjenstandsfunnene er det hele tonet kraftig ned. Han forklarer at informasjonen om at det skulle være funnet gjenstander av bronse, måtte være basert på en misforståelse, og at det var glødeskallet på enkelte av 
gjenstandene som hadde gjort at folk snakket om at disse måtte være laget av et annet metall enn jern. Videre fremhever han at finnerne hele tiden har handlet i god tro (Marstrander 1943c). Hos Grieg er hele den triste episoden fraværende; han skriver at de nye gjenstandene først kom for dagen i mai, og at museets representant reiste til Haugsbygd straks man fikk melding om funnet (Grieg 1947:2).

Det viste seg at Gunnar Gjermundbo hadde gjort de nye funnene på to ulike steder i haugresten. Ca. $8 \mathrm{~m}$ vest for det det tidligere funnet (dvs. deponering 1) hadde han funnet en øks under en steinhelle; ovenpå steinen lå en spydspiss og ved siden av steinen et sverd. Gjenstandene lå ca. 0,5 m under haugoverflaten, og var dekket av en steinpakning av samme type som ved deponering 1. Det ble ikke observert kull eller brente bein. Vi benevner dette komplekset deponering 3 .

Ca. 1,5 m vest for deponering 1 var det blitt observert et rundaktig område med kullflekker og «ganske mange» beinsplinter (deponering 4). I en del av disse flekkene lå det flere gjenstander. Marstrander antok at dette kunne være selve likbrenningsstedet (Marstrander 1943c).

Hvilke gjenstander som var blitt funnet i deponering 4, fremgår ikke klart, verken av Marstranders innberetning eller av Griegs publikasjon. Sistnevnte opplyser bare at det ene munnbittet i det samlede funnet lå her, men at det ikke lenger kan avgjøres hvilket (Grieg 1947:5). Marstrander selv gir bare en antydning når han i rapporten skriver om de gjenstandene som noen hadde ment måtte være av «bronse». Han presiserer nemlig at det dreier seg om «et bissel, en spydspiss og et par andre jernsaker», og det er tydelig at dette er saker som er funnet etter at den første etterundersøkelsen var avsluttet (Marstrander 1943c). Den
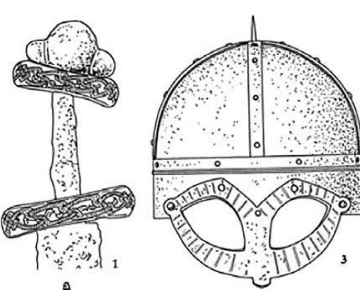

(堣)
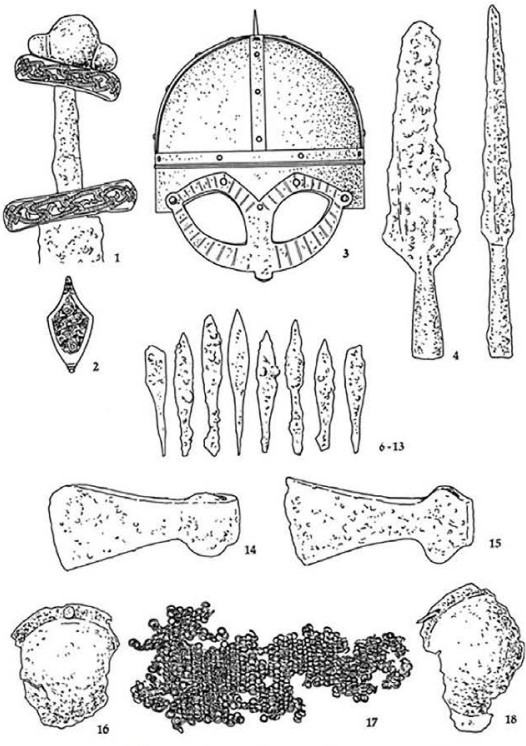
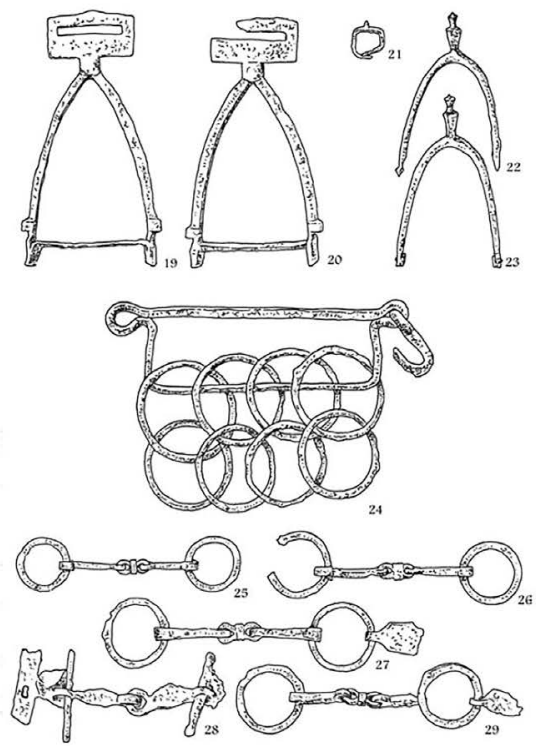

Figur 7. Våpen og rideutstyr fra Gjermundbu. Etter Müller-Wille 1972, Abb. 22-23. 
eneste spydspissen vi vet ble funnet etter 2. april, er den som lå i deponering 3. Da gjenstår det nevnte munnbittet og «et par andre jernsaker».

Det er sannsynlig at C27317 3t, en del av klingen til et enegget sverd eller en stor våpenkniv, er blant de sistnevnte, selv om Grieg plasserer den i sin grav II. Hvilket av de seks munnbittene i det samlede funnet som hører til Deponering 4, er som nevnt usikkert. Ettersom munnbittet ikke nevnes blant de gjenstandene som er funnet etterpå, verken i politirapporten eller i en samtale Lars Gjermundbo hadde med Jon Guldal 15. mai (Grylling 1943; Guldal 1953), samtidig som det nevnes et antall på fem (hele?) munnbitt allerede tidlig i april (Ringerikes Blad 2. april 1943), kan det være at det er den løse ringen til et munnbitt, C27317 w, det dreier seg om.

\section{Deponeringer, graver og datering}

Hva representerer så de ulike deponeringene i gravhaugen på Gjermundbo? Graver i vikingtid er materielle levninger etter kompliserte ritualer (Gjerpe 2005; Ulriksen 2011). Det har derfor vært pekt på at det som tradisjonelt har vært oppfattet som ulike «graver» i én og samme haug, like gjerne kan tolkes som spor etter ulike deponeringer og handlingsrekker (Barndon og Olsen 2018). Marstrander og Grieg mente at det vi her har kalt deponering 1 og deponering 3, representerte to forskjellige graver (henholdsvis grav I og grav II).

Vi finner ingen avgjørende grunner til å gå bort fra dette standpunktet, men dateringsmessing er det ikke noe egentlig grunnlag for å skille deponeringene 1 og 3 fra hverandre, ettersom begge tilhører siste del av 900-årene. Det kan derfor ikke utelukkes at de representerer samtidige hendelser og ulike handlingsrekker i forbindelse med én og samme gravlegging.

Hva da med deponering 2? Denne representerer, som nevnt, et tykt lag med kull og brente bein som ifølge Marstranders innberetning lå «like ved» grav I. De originale tegningene viser imidlertid at dette laget ble påtruffet $7-8 \mathrm{~m}$ vest for deponering 1 / grav I, det vil si mer eller mindre på samme sted som deponering 3 / grav 3 senere kom for dagen.

Når det gjelder Deponering 4, virker Marstranders tolkning av dette som spor etter likbrenningen, rimelig (Marstrander 1943a, jf. Henriksen 2016). Det foreligger dessverre ikke opplysninger om hvor dypt i haugen dette laget lå, og informasjonen om lagets utstrekning er omtrentlig.

Brente bein fantes kun på det mulige likbrenningsstedet og i deponering 2. Det må være bein og trekull fra sistnevnte som er katalogisert under C27317 3p, 3 q og 3r. Beinfunnet har senere vært til osteologisk analyse, og viste seg å bestå av brente bein av et voksent, kraftig bygd menneske, sannsynligvis en mann, og ubrente og moderat brente dyrebein (Holck 1986:286). Trekullet er i museets tilvekst bestemt som ask (Fraxinus), hassel (Corylus) og gran (Picea).

Plasseringen i haugen taler for at det er en sammenheng mellom deponeringene 2 og 3 , kanskje også mellom 1 og 4. En alternativ tolkning av situasjonen kan være at deponering 4 representerer den primære hendelsen (kremasjonen), og at restene fra likbålet deretter er blitt fordelt på de tre andre deponeringene og forseglet av henholdsvis et kullag og en steinpakning (1) og en steinpakning (3 og kanskje også 2).

Dette er en summarisk oversikt over gjenstandenes fordeling på de fire deponeringene, forøvrig vises til Griegs katalog (1947): 
Deponering 1 / «grav I»: tveegget sverd, doppsko til sverdslire, 2 økser, 2 spydspisser, 8 pilspisser, 4 skjoldbuler, brynjevev, hjelm, 3 spillebrikker av bein, 3 terninger av bein, rangle, 2 stigbøyler, 2 sporer, 5 munnbitt, hovbeslag/isbrodd, 4 sledekroker, 1 krok, 4 kniver, celt, fil, 2 bryner, sigd, saks, 3 remspenner, ildstål, 2 brannjern/-føtter, ristil?, stekepanne, kjele, skjerding med krok og virvel, hadde til trespann, rembeslag, hengelås, slå til skrin, 2 skrin-/kistehengsler, 9 skrinhengsler, kistebeslag og en del mindre beslag, spiker, nagle mv.

Deponering II: brente dyre- og menneskebein.

Deponering III / «grav II»: tveegget sverd, øks og spydspiss.

Deponering IV / kremasjonslaget: munnbitt, enegget klinge og brente bein.

Så til dateringen av funnet/-ene. Gjenstandene i deponering 3 består av et sverd som er en mellomting mellom Petersens type $\mathrm{M}$ og hans type $\mathrm{Q}$, med nedadbøyd underhjalt og rett overhjalt, en øks av Petersens type F og en spydspiss av type G/Solbergs type IX.1A. Samtlige er med andre ord av sene vikingtidstyper, og spydet daterer deponeringen til tiden etter ca. 950 (Petersen 1919; Solberg 1984).

Deponering 1 inneholder langt flere gjenstander, hvorav flere som kan bidra til en nærmere datering. De etter hvert ikoniske gjenstandene, hjelmen og brynjeveven, gir ingen gode holdepunkter. Det gjelder også rytterutstyret i form av sporer og stigbøyler. Hva våpnene angår, er typer og datering gjennomgått av Helge Braathen, som har korrigert enkelte av Griegs typebestemmelser (Braathen 1989:87-88). Her finnes to økser, begge av Petersens K-type, fire skjoldbuler av typen R563 og to spydspisser, henholdsvis av Solbergs type IX2A og VII.2A. Sistnevnte type er ifølge Solberg «from highly specialized workshops» (Solberg 1984:107, jf. Blindheim 1963, Martens 2002). Grieg anfører ellers at ingen av spydspissene i funnet har dekor, mens Braathen (1989:87) påpeker at den ene (C27317 d) er dekket av sølv og kobbermetall i geometrisk dekor på falen. Ranglen og det ene munnbittet peker også mot yngste vikingtid. Det praktfulle sverdet er av Petersens S-type / Geibigs kombinasjonstype 10, og har som doppskoen dekor i jellingstil. Typen er funnet i daterbare kontekster fra annen halvdel av 900-tallet og inn på 1000-tallet. Det er rimelig å følge Braathens datering av deponering 1 som helhet til sent i 900-årene (Braathen 1989:88).

\section{Funnstedet og miljøet}

Gjermundbu ligger ved foten av Ringkollen øverst i Haugsbygd, høyt og fritt med vid utsikt over Haugsbygd og Ringerikssletta, Randselva, Randsfjorden, Tyrifjorden og fjellene mot Hallingdal i vest. Gjermundbu ligger i utkanten av de rike arkeologiske miljøene i Haugsbygd, der først og fremst de store Sætrang-gårdene er godt kjent gjennom funnet av en velutstyrt kammergrav fra yngre romertid (Slomann 1959). Funnstedet på Gjermundbu ligger ca. 2 km fra Sætrang. Ringeriksbygdene som sådanne er et av Norges fremste jordbruksområder, og funn og fornminner viser sammen med skriftlige kilder og stedsnavn at landskapet har vært sentralt også i forhistorisk tid. «Det er sølvklokkeklang i navnene, og alle er de søndagsbarn blant bygdene våre», skriver Jon Guldal om gårdene på Ringerike (Guldal 1955:29). 
Funnstedet ligger 300-400 m fra det historiske tunet på Gjermundbu. Gjermundbu er trolig fradelt nabogården Bølgen, kan hende i vikingtiden (Slåtto 1979:27). Funnstedet ligger nær grensen mot markene til nabogårdene Bølgen, Lo og Færden, og det har vært foreslått at gravhaugene i Vesleenga heller bør oppfattes som tilhørende Bølgen (Bakke 1995:48, 1997:25).

Forbi funnstedet går den eldgamle ferdselsveien mellom Hadeland og Ringerike:

Her efter den gamle vei gikk soldater til krig, prester, bønder, munker og folk som hadde sekk og tiggerstav. Fra haugen ser en det meste av Ringerike, bl.a. hele Røysebygda og til venstre Storøya, hvor Hamarbispen engang hadde sin sommerresidens og med sitt følge kom her forbi. (Guldal 1936)

Den største av gravhaugene i Vesleenga har vært godt kjent i lokalmiljøet, men er ikke nevnt i Norske fornlevninger (Nicolaysen 1866) eller i eldre topografisk litteratur. Wiel skriver midt på 1700-tallet at det er «mangfoldige Jordhouger» i Haugsbygd, «men som de hverken ere udgravne, eller der fortælles noget om dem, ikke heller findes nogle Stene oprejste paa dem, og altså intet merkværdigt bekjendt om dem, har jeg med Forsæt gaaet dem gandske forbi» (Wiel 1933:31). Vi kommer nærmere tilbake til denne gravhaugen.

I middelalderen tilhørte Gjermundbu ulike kirkelige godseiere; både kommunet ved Mariakirken i Oslo og prosten der hadde eierparter, mens erkebiskopen i Trondheim eide en større part. Eierparten i Gjermundbu var den eneste erkebiskopen hadde på Ringerike. Ytterligere en part lå til presten i Norderhov (Halvorsen 1955:22-23). De spesielle eiendomsforholdene er en indikasjon på at gården i sin tid har tilhørt kongemakten eller en annen stor, verdslig godseier, og at de sentralkirkelige institusjonene har fått sine eierparter gjennom donasjon på et tidlig tidspunkt, kan hende allerede ved det tidspunktet institusjonene ble opprettet og dotert (jf. Skre 1998:93-95).

Når det gjelder vikingtiden på Ringerike, hevder Grieg at de fleste funnene «på et par unntak» ikke er særlig representative, «og vitner i grunnen bare om den grå hverdag» (Grieg 1947:65). Hans sammenligningsgrunnlag er trolig de store gravfeltene og rike funnene fra romersk jernalder og folkevandringstid på Veien og Sætrang, først og fremst (Slomann 1959; Gustafson 2016). Men det er vanskelig å si seg enig med Grieg. Særlig fra Hole, lenger sør på Ringerike, har man rike vikingtidsfunn. Med utgangspunkt i disse og den senere kongsgården Stein med Halvdanshaugen, en av landets største og mest monumentale gravminner, har det tvert imot vært foreslått at funnbildet tyder på en forskyvning av maktforholdene fra Norderhov og Haugsbygd til Hole i yngre jernalder (Stylegar 2004).

\section{Grav og gravskikk på Gjermundbu}

«Den gravform vi møter i Gjermundbugraven, brannflaket, er så velkjent i Norge i vikingetiden at vi ikke her behøver å dvele nærmere ved den», innleder Grieg sin gjennomgang av gravskikken (1947:13).

Kremasjons- eller likbrenningsskikk (dvs. at den døde kremeres) og branngravskikk (dvs. at kremasjonsrestene blir begravd) er kompliserte temaer, og branngravene er på ingen måte en enhetlig gruppe (Henriksen 2016:1). Begrepet «branngrav» dekker et helt spekter av mer eller mindre distinkte «gravtyper». Brannflaket representerer, som Grieg påpeker, den mest utbredte vikingtidsgravskikken her i landet, etter det arkeologiske materialet å dømme. I brannflaket er bålmørje fra likbålet spredt ut over et større areal på haugbunnen, 
av og til på samme sted som likbålet stod. Av og til er det satt ned et leirkar eller en annen beholder (jernkjeler, kleberkar, ovalspenner, skjoldbuler etc.) i brannflaket, med en del av de brente beina.

På Østlandet er det kremasjonsriten som rår grunnen i vikingtiden. Videre vestover langs Norskekysten blir jordfestegravene imidlertid gradvis mer vanlige. Brannflak er den dominerende branngravskikken på Østlandet. Ved Oslofjorden, og med et kjerneområde i Østfold og på Romerike, finnes imidlertid urnebranngraver ved siden av det vanlige brannflaket. Noe stort antall dreier det seg ikke om, men det er mange nok til at de utgjør en karakteristisk kontrast til brannflaket. I disse gravene er det i mange tilfeller et kleberkar, sjeldnere en kjel av jern, som er benyttet som beingjemme.

Griegs tolkning av Gjermundbu-graven som et primært brannflak, hviler ene og alene på tolkningen av opplysningene om spredte bein i deponering 4. Det kan være at han har rett, som vi har vært inne på, men noe typisk brannflak er det uansett ikke. De brente beina i gravhaugen ser jo ut til å ha vært (re)deponert i deponering 2, flere meter fra «hovednedleggingen» i deponering 1 . Og det foreligger ikke noen informasjon om at det ble funnet brente bein i deponering 1. Dersom deponering 1 og deponering 4 faktisk tilhører samme fase, er i så fall deponering 1 («grav 1») satt ned i/under brannflaket. Dette er ikke en utbredt gravform i norsk vikingtid, men det finnes enkelte eksempler.

Mest kjent er den brente skipsgraven på Myklebost i Nordfjord, som ble undersøkt av Anders Lorange i 1874, og der et insulært hengekar av bronse var fylt med kremasjonsrester og personlig utstyr og satt ned i en grop under brannflaket (Shetelig 1912:200-201, jf. Stylegar 2021, i trykk). En lignende gravform er kjent fra enkelte østsvenske merovingertidsfunn (Lindqvist 1921:92).

\section{Den hvelvede jernkjelen}

I haugen på Gjermundbu lå jernkjelen hvelvet over de fleste av gjenstandene i deponering 1. Ettersom brynjeveven lå ovenpå den hvelvede kjelen, må kjelen ha vært plassert med bunnen opp fra begynnelsen av. Grieg drøfter dette, og gir en del eksempler på det samme fra andre gravfunn (Grieg 1947:13-14). Han mener at «jernkjeler med bunnen i været synes å være et konservativt trekk i gravskikken» (1947:16).

Det er mange eksempler på dette fenomenet på Østlandet; det vanligste er at et kleberkar eller en jernkjel er hvelvet over de brente beina i et brannflak. Fra Hedmark kjenner vi for eksempel fire eksempler på hvelvede kar i brannflak, fra Østfold fire og fra Bohuslän fem. ${ }^{2}$ Skikken forekommer mer spredt også ellers i landet, og i enkelte jordfestegraver.

Grieg går ikke inn på hva slags forestillinger som kan ligge bak denne skikken, og hva som har gjort praksisen meningsbærende. Innenfor samisk tradisjon var en lignende bruk knyttet til forestillinger om at noen døende mennesker har en «lett» sjel, andre derimot en «tung» en; dersom en person på dødsleiet ikke vil slippe taket, men befant seg «mellom verdenene», kunne man fremskynde døden ved å hvelve en (kobber)kjel ved siden av den døende (Nordkild 2020).

Den samme praksisen er kjent også i sørnorsk tradisjon (Lunde 1969:38-39). Fra Sunnmøre fortelles videre at rydningsmenn alltid førte med seg et kar, og når de kom til et sted der en gård kanskje kunne ryddes, hvelvet de karet over seg. Fikk de hvilt og sovet godt, tok de det som et godt varsel (Storaker 1938:160). I Agder spilte også hvelvede kjeler en viktig rolle når ny hustomt skulle velges; når en hadde funnet en passende byggetomt, 


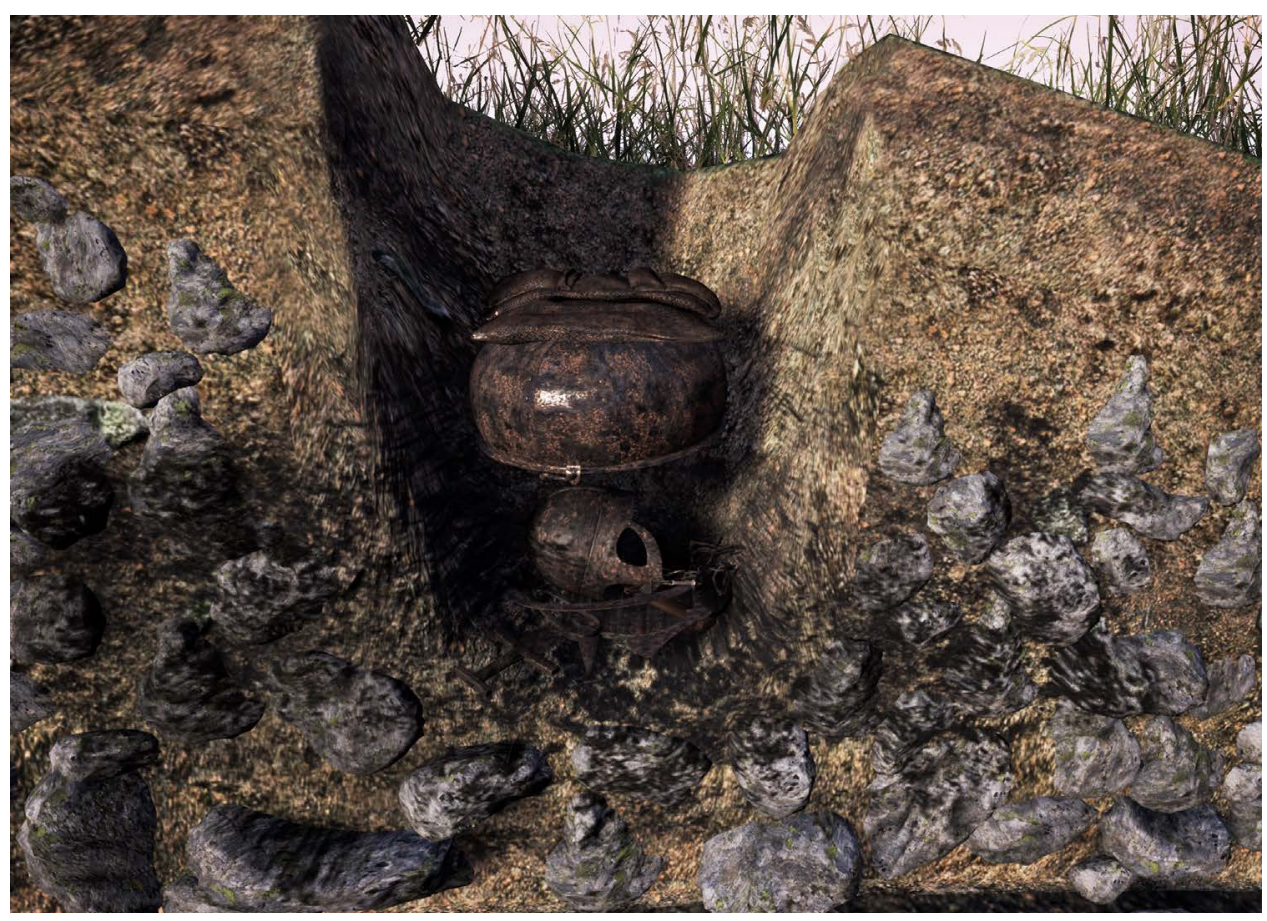

Figur 8. Deponering 1, rekonstruksjon basert på Marstranders skisser og foto.

Illustrasjon: Ragnar L. Børsheim.

kunne man plassere en hvelvet kjel på stedet, og dagen etter tok man varsler av hva som fantes under den.

\section{Sleden}

I funnet fra 1943 ligger fire såkalte sledekroker av jern (type Rygh 466) og dessuten en rangle (Rygh 460). Sledekrokene har «i høy grad en østlig utbredelse», og Jan Petersen kjente i 1951 ingen funn fra og med Aust-Agder til og med Hordaland (Petersen 1951:58). Foruten Vestfold er det innlandsdistriktene på Østlandet som har flest funn, og en del eksemplarer kjennes også fra Sverige og Finland. Det er vanligvis én sledekrok i hvert funn, men det finnes enkelte andre eksempler på så mange som fire kroker (Tolstad i Gudbrandsdalen og Vendel grav 14; Petersen 1951:61; Nordahl 2018:53-54).

I én av gravene fra Röstahammaren i Jämtland ble en sledekrok funnet i en kontekst som gjør det utvilsomt at det faktisk er tale om en gjenstand som har hørt til en slede (Kjellmark 1905, 1939; Müller-Wille 1998). Selve funksjonen har vært gjenstand for atskillig diskusjon, men det dreier seg trolig om enten en festeanordning for skjæker eller trekksnorer til styring (Almgren 1946; Petersen 1951; Lund 1974).

Isolert sett kan det vanligvis ikke avgjøres om sledekroker i gravfunn har tilhørt vogner eller sleder, men det er utvilsomt at sleden har vært et utbredt transportmiddel i Skandinavia, med eksempler fra langt tilbake i forhistorisk tid (Berg 1935), og at vogner i hvert fall for 
Norges del har vært et lite egnet kjøreredskap. Eldste daterte norske sledefunn er fra merovingertid (Bjørgo mfl. 2016).

Osebergfunnet viser at vikingtidens sleder hadde løs karm, dvs. at understellet kunne være enten hjul eller meier (Sindbæk 2003). Dette innebærer blant annet at de sørskandinaviske vognfatingsgravene i prinsippet like gjerne kan være fra sleder som vogner. Når det gjelder Gjermundbufunnet, underbygges tolkningen som slede (eller sleder) av at det også fantes isbrodder til hest, slik at begravelsen trolig har funnet sted vinterstid.

Sleder inngår i skipsgravene fra Oseberg, Gokstad, Tune og Storhaug/Karmøy (Marstrander 1986). Bildevevfragmentene fra Oseberg tyder på at sleden har hatt en funksjon i selve gravritualet (Vedeler 2019, jf. teppet fra Överhogdal og bildesteinen fra Levide på Gotland). Osebergfunnet skiller seg ut med tre prakt- eller paradesleder; kanskje én for hver av de gravlagte (jf. Androshuck 2005). Det bør nevnes som en mulighet at de fire sledekrokene i funnet fra Gjermundbo kan bety at det var to gravlagte.

Sledekrokene i det norske vikingtidsmaterialet er konsentrert i regioner som på flere områder viser østlig påvirkning, fra Svealandskapene og enda lenger øst (se også Arwidsson 1977; Gräslund 1980; Nordahl 2018). Det finnes en interessant kobling mot øst også når det gjelder sledens rolle i gravritene. Undersøkelser av graver som tradisjonelt har vært knyttet til skandinaviske leiekrigere (druzhina) i russisk tjeneste, som det berømte gravfeltet i Plakun ved Staraja Ladoga (Mikhailov 2005), har sannsynliggjort at nagler og jernbeslag i disse gravene er sleder som er lagt i gravene sammen med de døde (Sindbæk 2003). Sune Ambrosiani har i en artikkel pekt på den mulige sammenhengen mellom sledene i skandinaviske gravfunn og den rollen sledene spilte i øst, først og fremst i forbindelse med fyrstelige begravelser (Ambrosiani 1918). I Rusriket var skikken å legge en døende person på en slede, og liket skulle også transporteres på slede til gravstedet. Da fyrst Vladimir døde i Berestovo ved Kiev i 1015, ble liket ført til graven på en slede. Da to av Vladimirs sønner, Boris og Gleb, samme år blir drept av sin bror, forteller krøniken likeledes at likene ble lagt på sleder og båret inn i kirken for å gravlegges der. Det samme gjentok seg i 1054, da fyrst Jaroslav døde.

Kildene forteller at russiske fyrster og stormenn ble ført til graven på sleder også lenge etter den tid, og trolig også før. Sleden kom til å bli assosiert ikke bare med begravelser, men

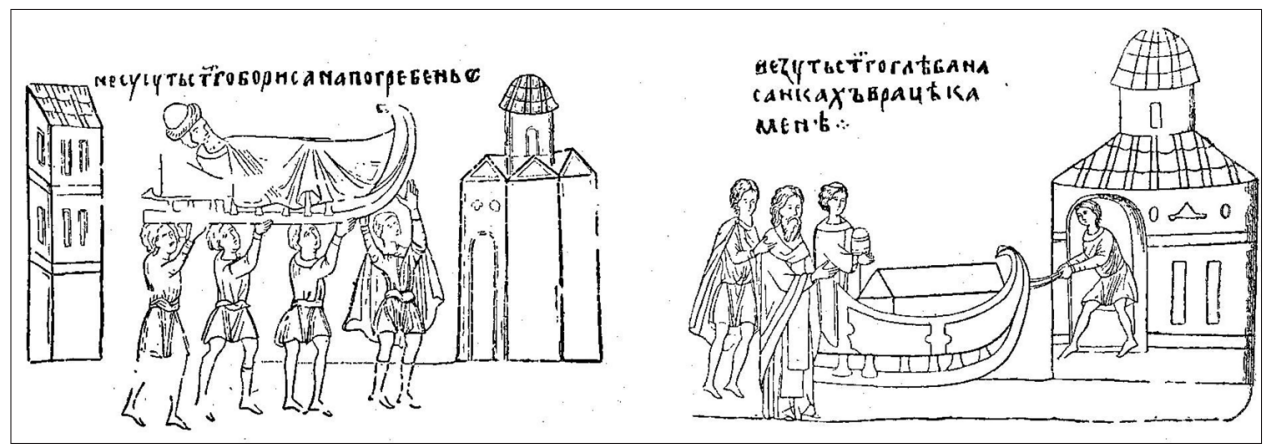

Figur 9. De drepte brødrene Boris og Gleb føres til sine graver i sleder. Fra Sylvesters bok, Novgorod, 1300-tallet. Original i Russian State Archives of Ancient

Documents. Etter Ambrosiania 1918, figur 2 og 3. 
med alderdom og død. Fyrst Vladimir Monomakh, som døde i 1125, etterlot seg et testament som innledes med formuleringen om han nå «sitter på sin slede», og som nettopp viser til at han er døden nær. Da Theodosius, Huleklosterets prior, ble alvorlig syk i 1074, bad han munkene om å bære ham ned i gården; de la ham på en slede og satte den foran kirken (etter Nestorkrøniken under angitte år, Svane 1983).

\section{Skipsformet haug}

Selve gravhaugen på Gjermundbu var som nevnt en langhaug, ca. $29 \mathrm{~m}$ lang og $9 \mathrm{~m}$ bred. Formen ser ut til å ha vært spissoval, med andre ord en skipsform. Dette er en uvanlig type gravminner. Trond Løken anfører at mens langhaugene i hans studieområde (Østfold og Vestfold) utgjør 2 prosent av gravminnene, utgjør de skipsformede gravminnene bare 0,5 prosent (Løken 1987:54). Løken mener at de «vanlige» langhaugene er symbolske hus, og han knytter dem til kvinnegraver (1987:62-63). I noen tilfeller har de skipsformede haugene vist seg å inneholde båtgraver (Farbregd 1988), og det er sannsynlig at formen har sammenheng med skipet som symbol i vikingtiden (jf. Vestergaard 2007).

Artikkelforfatterne har ikke kjennskap til andre skipsformede hauger på Ringerike, og typen ser generelt ut til å være knyttet til kystdistriktene (Myhre 2015:84). Gjermundbuhaugens størrelse plasserer den blant de aller største langhaugene på Ringerike, kanskje som den største.

Den skipsformede langhaugen var etter den sparsomme originaldokumentasjonen orientert ca. østnordøst-vestnordvest. Ut fra situasjonen på stedet er dette ikke urimelig, men en rett Ø-V-orientering er mer i tråd med opplysningene innhentet på gården på 1960-tallet (informasjon hentet fra Askeladden, ID 3888). Dataene i Askeladden plasserer imidlertid haugen $24 \mathrm{~m}$ vest for den store rundhaugen på stedet, hvilket ikke kan være riktig. Marstrander skriver at langhaugen lå «rett søndenfor» den andre, men «søndenfor» gir ikke mening her (Marstrander 1943a). Trolig mente han «vest for». En samtidig avisreportasje angir «5-6 meter» (Ringerikes Blad 2. april 1943).

For en som beveget seg gjennom landskapet, enten nordover i retning Hadeland eller sørover i retning Norderhov, må det ha fortonet seg som om «skipet» så å si var på vei ut av den store rundhaugen ved siden av - eller inn i den.

\section{Storhaugen}

Første gang rundhaugen er omtalt i skriftlige kilder, ser ut til å være i 1933. Da diskuterer Jon Godal den i en avisartikkel, og legger til at haugen er «en av de største og fineste jeg har sett i denne trakt», og at «stikker man et spett eller en jernstang gjennem torven på haugen så går den lett nedigjennem og en kan derfor formode at haugen er hul» (Guldal 1933). Guldal foreslo at haugen var bygd over en «bygdekonge».

Den monumentale haugen er av betydelig størrelse. Marstrander anslår diameteren til 35 m og høyden til 5 m (Marstrander 1943a). Ikke mange gravhauger på Ringerike er like store. Halvdanshaugen på Stein er med sine $58 \mathrm{~m}$ i diameter i en klasse for seg, men haugen på Gjermundbu er en god kandidat til å være nest størst. Den har aldri vært undersøkt nærmere, og det er ingen opplysninger om funn eller andre observasjoner.

Både gjennom dimensjoner, uttrykk og plassering slutter rundhaugen i Vesleenga seg til gruppen av de virkelige storhaugene på Østlandet - som Sveinhaugen i Ringsaker, haugene på Huseby i Lier, rundt Åker på Hedemarken, på Hundorp i Gudbrandsdalen og stedvis 


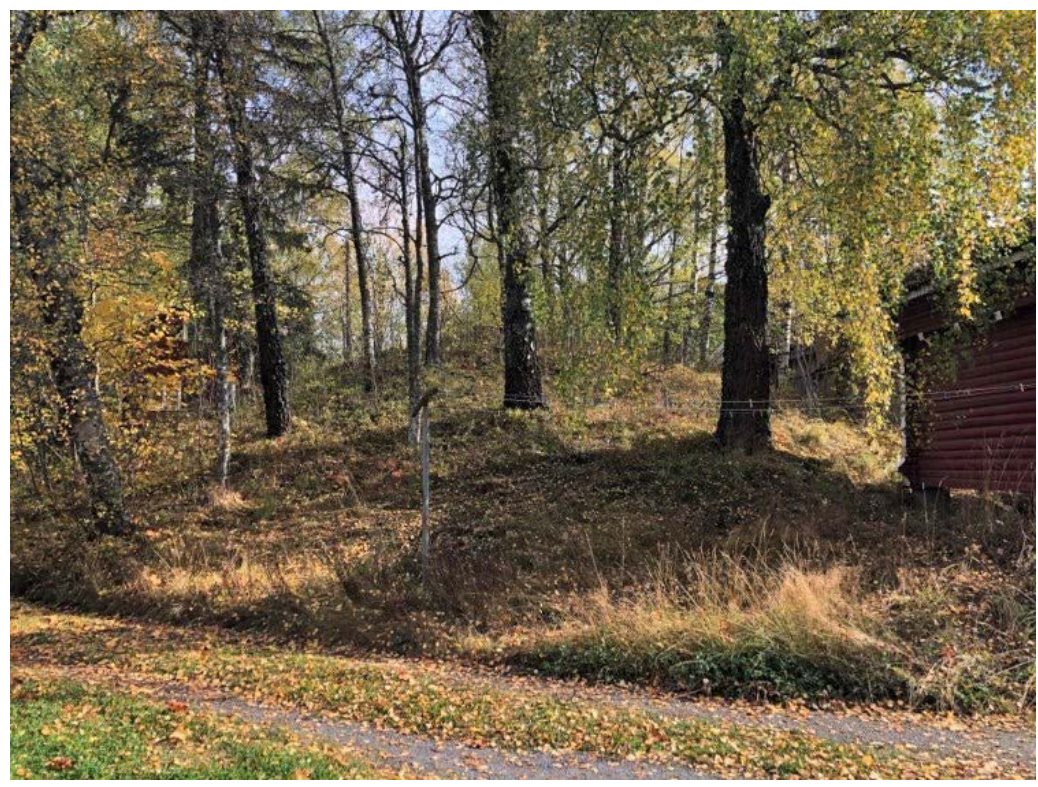

Figur 10.

Den store

gravhaugen, sett fra vest.

Foto:

Frans-Arne H.

Stylegar,

2020.

langs Glomma, for ikke å glemme den største av dem alle, Raknehaugen på Romerike (Myhre 1992:170-171). Disse haugene ligger oftest enkeltvis, sjelden mer enn én på hvert sted (Brøgger 1937:150). Tyngden av dem ligger på Opplandene og på Romerike, og man regner med at de tilhører 500- og 600-tallet (Brøgger 1937:150; Skre 1997).

Brøgger mener at storhaugsfenomenet på det indre av Østlandet henger sammen med utviklingen av «kungshögar» i Uppland på samme tid (1937:161), og Myhre argumenterer for at storhaugene markerer småriker (Myhre 1992:165).

Sannsynligheten taler altså for at rundhaugen på Gjermundbu hadde ligget der i tre-fire hundre år da den skipsformede pendanten ble bygd. Plasseringen av sistnevnte er selvsagt ingen tilfeldighet. Det er vel heller slik at den monumentale storhaugen har vært en viktig lokaliseringsfaktor for langhaugen. Denne og andre måter å trekke veksler på eldre minnesmerker på, er påvist i ulike vikingtidskontekster (Pedersen 2006). Graver fra vikingtid opptrer som sekundærgraver i eldre gravminner, eller i form av nye gravhauger på gårdsgravfelt med røtter i romersk jernalder eller tidligere, men som ikke har vært benyttet på mange generasjoner. Vikingtidsgraver er også påtruffet i gårdsanlegg og nausttufter som var gått ut av bruk lenge før vikingtiden (Stylegar 1997).

Denne praksisen er neppe uten sammenheng med de omfattende endringsprosessene som vikingtidssamfunnene i nord gjennomgikk. I det som på så mange vis var en oppbruddstid, kunne man gjennom en slik gravskikk symbolsk markere «røtter» og kontinuitet med for lengst henfarne tider. Dette kunne være et ledd i aristokratiske gruppers maktstrategier, idet man forsøkte å hente legitimitet fra fortidens helter og høvdinger, eller skikken kunne inngå som en del av mindre jordeieres strev for å legitimere sin eiendomsrett til gård og grunn. 


\section{Hjelm, brynje og østlige forbindelser}

På godt og vondt er det hjelmen og brynjeveven som har fått aller mest oppmerksomhet når det gjelder funnet fra Gjermundbu. Forklaringen er enkel: Gjermundbufunnet står alene blant vikingtidens gravfunn i Skandinavia, ingen andre funn inneholder hjelm eller ringbrynje. Dette står i kontrast til forholdene i den foregående merovingertiden, da både hjelm og brynje forekommer i en del funn, ikke minst i Sverige. Parallellene mellom Gjermundbu og f.eks. et funn som Valsgärde VI fra sent 600-tall, har fått enkelte til å foreslå at både hjelm og brynje var for antikviteter å regne da de ble lagt i graven på Ringerike tre hundre år senere (Capelle 1998). Også Grieg går langt i den retningen når han skriver at den kalottformede Gjermundbu-hjelmen «ikke var på mote dengang den ble lagt i graven», ettersom de typiske vikingtidshjelmene var koniske med nese- og nakkeskjerm (Grieg 1947:47).

Når det gjelder brynjeveven, nevner Grieg en håndfull funn fra Telemark og Trøndelag fra svært usikre funnkontekster, men som han antar kan være fra vikingtid (Grieg 1947:18, jf. Vike 2000). For øvrig representerer Gjermundbufunnet en enslig svale i skandinavisk sammenheng, selv om ulike skriftlige kilder, bildefremstillinger og funn fra andre kontekster enn graver viser at rustninger i ulike utforminger har vært kjent (Grieg 1947:17, Stjerna 2004). Av samme årsak har det vært foreslått at brynjeveven fra Gjermundbu er et importstykke, fremstilt enten i Frankerriket eller i østlige områder (Szameit 2001:261).

Det finnes en håndfull kjente paralleller til den hjelmtypen vi kjenner fra Gjermundbu. Med et mulig unntak for hjelmen fra Yarm (Yorkshire), som utelukkende er datert gjennom likheten med Gjermundbu-hjelmen, dreier det seg om fragmentariske funn (Caple 2020). Fragmentene fra Lokrume (Gotland) og Tjele (Jylland) trekkes ofte frem; sistnevnte inngår i et verktøysdepot, og kan representere gjenbruksmetall (Munksgaard 1984). Et annet hjelmfragment av samme type er et løsfunn fra Tiendekirken i Kiev (Kirpichnikov 1971: 24, jf. Androshchuk og Zotsenko 2012:73). Kiev-fragmentet har usikre funnomstendigheter,

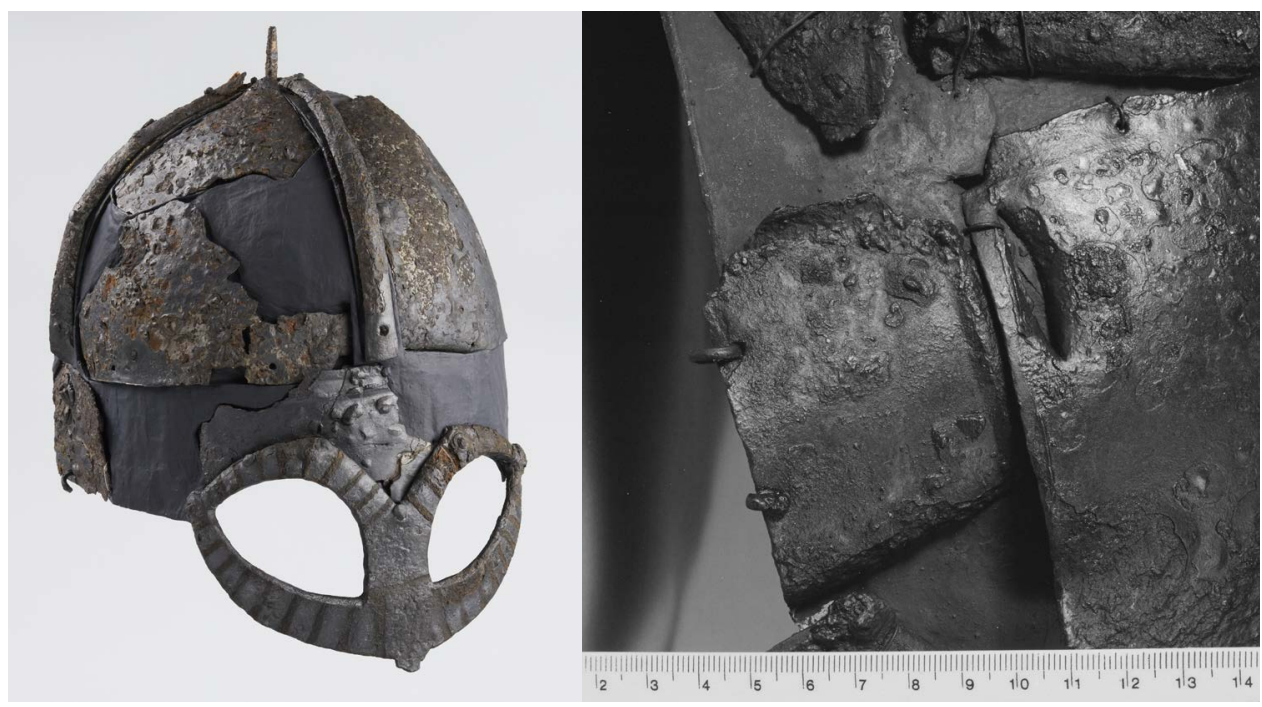

Figur 11. Gjermundbu-hjelmen. Foto: Vegard Vike/Kulturhistorisk museum, UiO. CC BY-SA 4.0. 
men kan skrive seg fra en grav, ettersom området ved Tiendekirken omfattet én av de større gravgruppene fra vikingtiden i Kiev (Ivakin 2012).

Men ved å omformulere spørsmålet kan vi kaste nytt lys over gjenstandene i Gjermundbugraven. For hva om vi i stedet for å lete etter typologiske paralleller til hjelm og brynjeveven fra Gjermundbu, ser etter kontekstuelle paralleller? Finnes det andre gravfunn fra perioden der hjelm og/eller brynje inngår? Ut fra diskusjonen om Gjermundbufunnet som noe unikt, skulle man tro at svaret var «nei», men slik er det faktisk ikke. De gangene hjelmen (og brynjen) fra Gjermundbu presenteres som enestående («Europas eneste vikinghjelm»), er utgangspunktet snevert vesteuropeisk, eller skandinavisk. Lenger øst er nemlig hjelm og brynje karakteristiske, om enn fătallige, innslag i rikt utstyrte mannsgraver nettopp fra 900årene. ${ }^{3}$

Det dreier seg om graver og gravplasser i det nåværende Russland og Ukraina, som dels knyttes til Rusrikets herskere og deres nærmeste krets, dels til deres (skandinaviske) hird (druzhina).

Flere av gravene i Gnezdovo ved Smolensk inneholder hjelmer og ringbrynjer (Duzcko 2004:161-162). I haug 18 (Centralnaja-gruppen) var en hjelm plassert ovenpå en brynjevev på toppen av et brannflak sammen med en del våpen (Duczko 2004:172). I haug 24 (den monumentale Olshanskii-kurganen i Olshanskaja-gruppen, 6,7 m høy og $37 \mathrm{~m}$ i diameter) fantes et stort brannflak, som blant annet inneholdt en mengde klinknagler. Midt i laget stod en bronsekjel fylt med blant annet brente bein og deler av en ringbrynje. Brente bein var også lagt i tre leirkar, og ved siden av dem lå en ringbrynje (Duczko 2004:170).

Storhaugene ved Chernihiv (Ukraina) kan oppvise lignende funn. I Chernaya Mogila («Svarthaug», $11 \mathrm{~m}$ høy og $40 \mathrm{~m}$ i diameter) fantes et stort brannflak. En mengde gjenstander fra likbålet lå samlet i dette laget, deriblant to hjelmer, fragmenter av én eller to ringbrynjer, to praktsverd (Petersens type $\mathrm{T}$ og Z), to par stigbøyler, to store drikkehorn beslått med forgylt sølv, spillebrikker, to bysantinske gullmynter, øks, 10 spyd, pilspisser og så videre. Ved siden av disse gjenstandene stod en jernkjel som inneholdt brente dyrebein (Duczko 2004:239-240). I en annen storhaug, Gul'bishe, fantes også en hjelm (Kirpichnikov 1971, katalog, nr. 3).

Fire av gravene i Bolshoe Timerëvo ved Jaroslavl inneholdt fragmenter av brynjevev (Duczko 2004:193). Hjelm og brynje forekommer dessuten i enkelte rikt utstyrte jordfestegraver i Rusriket. I Pìdgìrcì, øst for Lviv (Ukraina), fantes rester av en brynjeskjorte i en grav som også inneholdt blant annet et praktsverd av Petersens S-type (Liwoch og MüllerWille 2012). I en kammergrav i Kiev (Lysaja gora, grav 117) var en mann blitt gravlagt med ringbrynje, hjelm, sverd, øks, spyd, et par sporer og åtte pilspisser; ved siden av mannen lå en hest (Duczko 2004:224).

Parallellene mellom disse funnene, i særdeleshet kremasjonsgravene, og den samtidige graven fra Gjermundbu er klare.

Øvrige gjenstander i Gjermundbufunnet vitner først og fremst om den gravlagtes tilknytning til et internasjonalt kriger- og høystatusmiljø. Økser, spyd, sporer og stigbøyler er av typer som forekommer over et vidt område, på samme måte som terningene og spillebrikkene i funnet. De fire skjoldene i funnet er et uvanlig trekk som kun gjenfinnes i et fåtall gravfunn i Norge, og først og fremst i skipsgraver og større båtgraver (Grieg 1947:23).. Forøvrig forekommer skikken med å utstyre den døde med to skjold blant annet på Birka, og på enkelte gravplasser i Rusriket (Duczko 2004:164). I den grad vi kan sette likhetstegn 


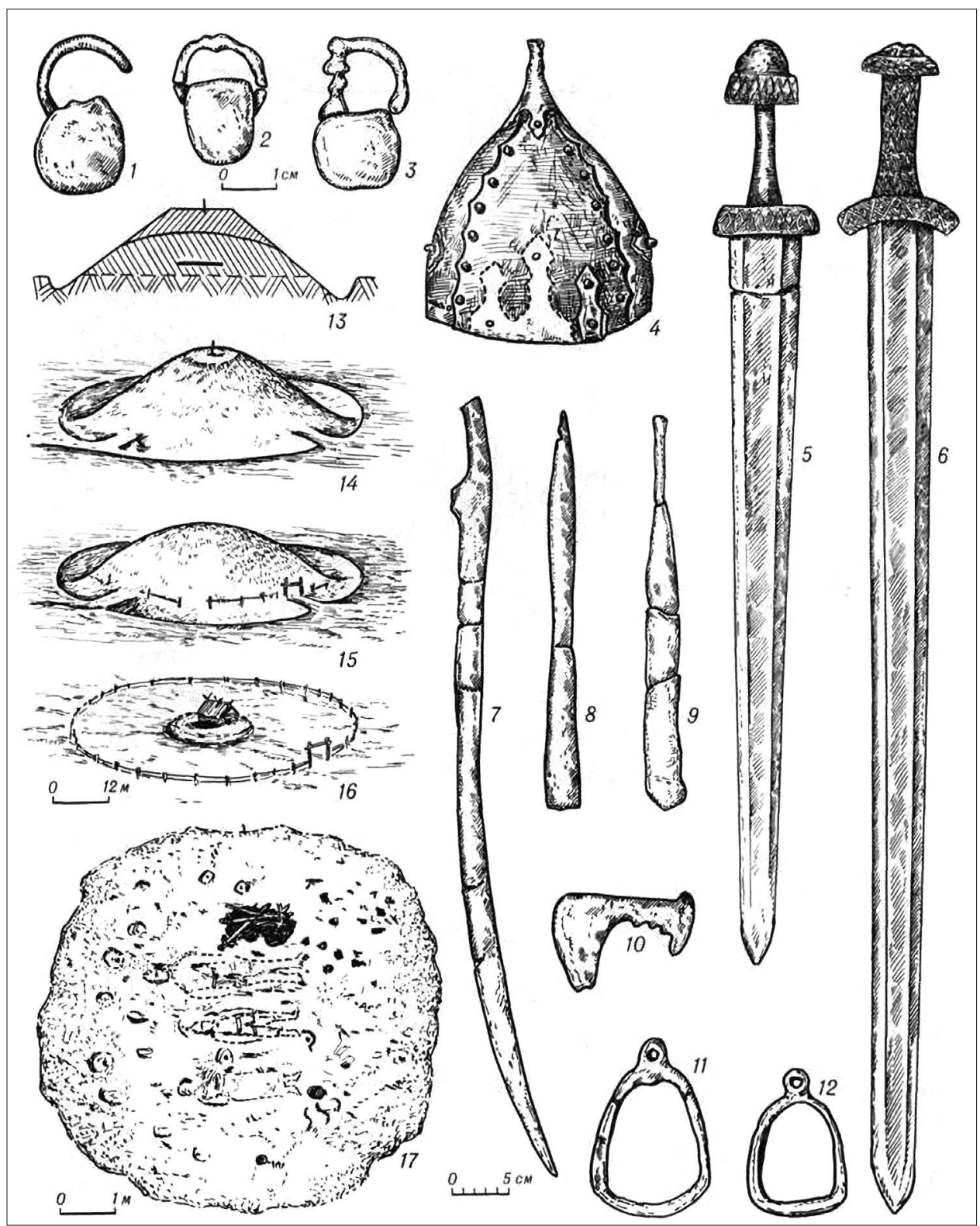

Figur 12. Noen av gjenstandsfunnene fra Chernaya Mogila, inkludert én av hjelmene. Etter Sedov 1982, Tavle LXXI. 
mellom de fem eller seks munnbittene i Gjermundbufunnet og det samme antallet ofrede hester, er graven likeledes usedvanlig; det er svært sjelden at det forekommer så mange hester i skandinaviske vikingtidsgraver utenom de store skipsgravene (Müller-Wille 1971, jf. Shenk 2002:57).

Det er som nevnt bevart åtte pilspisser i Gjermundbufunnet, samtlige av typen R539/ Wegraeus' type AI. De er trolig for kraftige til at de primært har vært benyttet til jakt, og det er kanskje ikke tilfeldig at bunter med slike pilspisser finnes i flere av ryttergravene på Østlandet (Braathen 1989). Duczko skriver at våpengravene i Kiev skiller seg ut med å ha et stort antall pilspisser, og han peker på parallellen med kammergravene i Birka i så måte (Duczko 20014:217). Bunter med piler er kjent fra flere av skipsgravene, men også fra en hel del mer ordinære våpengraver i Norge, og uten at man kan peke på noe tydelig geografisk tyngdepunkt. For eksempel inneholder så mange som seks av gravene på Kaupang bunter med pilspisser (Blindheim mfl. 1999:106-107).

Den eneggede klingen fra deponering 4 er med sine 3,7 cm klart smalere enn en typisk sverdklinge fra vikingtiden (Petersen 1919:10), og dateringen til sent 900-tall er et argument for at det kanskje ikke dreier seg om et sverd. Det er interessant å trekke paralleller til en type store våpenkniver som oppstår i Mälar-landskapene omkring 900, og som også forekommer i Russland og Ukraina (Vlasatý 2015). Tveeggede sverd forekommer sammen med en slik våpenkniv blant annet i vendelgravene og i Valsgärde båtgrav 12 og 15, samt i flere av kammergravene i Birka (Stolpe 1912; Arbman 1940; Duczko 2004:172; Ljungkvist 2008).

Når det gjelder det praktfulle S-sverdet med sølvbelagte og dekorerte hjalter fra deponering 1, er rundt 90 eksemplarer av denne sverdtypen kjent i Europa. I Norge ligger tyngdepunktet på Østlandet med Gudbrandsdalen og i Trøndelag, og på Ringerike har man to funn i tillegg til Gjermundbu. De norske funnene av S-sverd er i stor grad knyttet til ryttergravene fra sent 900- og tidlig 1000-tall (Andersen 2004:104). Foruten i Skandinavia forekommer typen først og fremst i sentrale og østlige deler av Europa (Müller-Wille 1972; Marek 2005; Kotowicz mfl. 2013), ofte i velutstyrte graver.

Det har vært foreslått at S-sverdene i Rusriket, i det nåværende Polen og på Den pannoniske sletten kan ha sammenheng med skandinaviske leiekrigere, i de to sistnevnte tilfellene knyttet til det tidlige Pjast-dynastiet, det vil si Mieszko 1. (ca. 960-992) og Boleslaw 1. (992-1025), og til de ungarske herskerne Géza (972-997) og Stefan 1. (997-1038) (Bakay 1967; Schulze-Dörrlamm 2012; Wadyl 2019). At det var knyttet status til S-typen, understrekes av en samtidig miniatyr som viser kroningen av keiser Otto 2. med et S-sverd hengende i beltet. Schulze-Dörrlamm foreslår som én mulighet at dette sverdet kan ha vært en gave fra danekongen (Schulze-Dörrlamm 2012:627). Ellers har Hedeby og Gotland vært trukket frem som mulige produksjonssteder (Geibig 1989; Gustafsson 2013, jf. Grieg 1947:31).

Grieg skriver om doppskoene at de representerer en «moteretning som var praktisk talt ukjent i Norge» (Grieg 1947:212). Vi kjenner til sammen 12 funn av doppsko fra vikingtiden i Norge, inkludert nyere detektorfunn, og igjen med tyngdepunkt i Trøndelag og det indre Østlandet. Til sammenligning har Sverige 49 funn, Øst-Europa 38 funn og de baltiske landene 29 funn (Androshchuk 2014:124). Den østlige dominansen er med andre ord stor, og skikken med å utstyre sverdskjeden med en ornert doppsko av bronse kan ha kommet til Skandinavia fra Rusriket og tilstøtende områder lenger sør (Steuer 1970:370). Generelt skriver doppskoene seg fra usedvanlig rikt utstyrte graver, når de da ikke er løsfunn eller kommer fra boplasskontekster (Sikora 2003:12, 2013:363). 


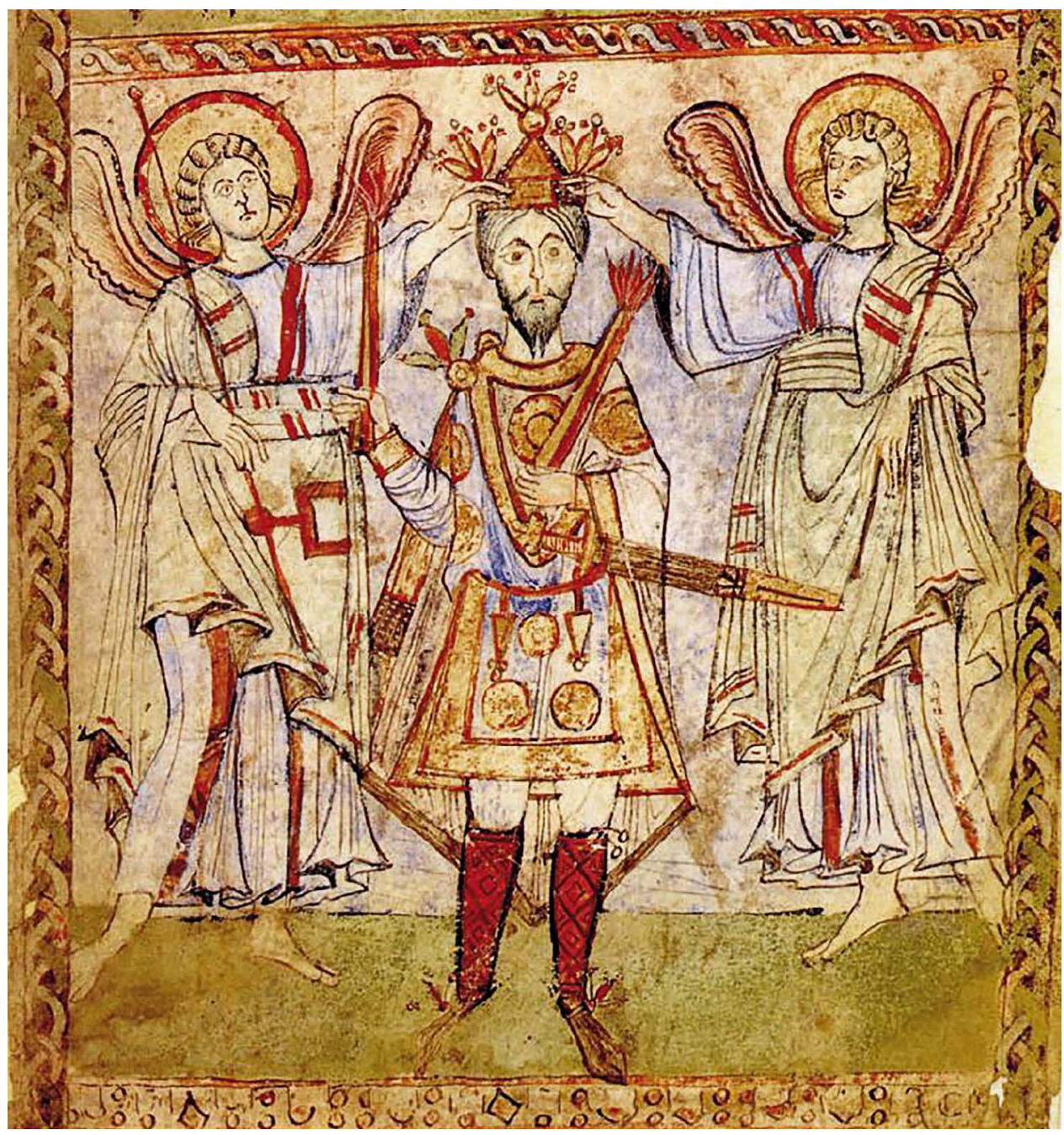

Figur 13. Keiserportrett, antagelig av Otto 2., som krones av engler og barer et $S$-sverd $i$ beltet. Miniatyr fra en exultetrull fra erkebiskop Landolf 1. av Beneventos tid, 985-

987. Original i Vatikanbiblioteket, Vat. Lat. 9820. Etter Schulze-Dörrlamm 2012, Abb. 11.

Motivet på doppskoen fra Gjermundbu er to sammenflettede, større og firføtte dyr med ryggen mothverandre, Paulsens type II.2 og Androshchuk type 6b (Paulsen 1953; Androshchuk 2014). Ingen av de andre norske funnene er av samme type; Paulsen anfører ni funn, fem av dem fra Sverige, de øvrige fra Finland og Russland (Paulsen 1953). Et nyere funn fra Chatburn (Lancashire) endrer ikke inntrykket av at utbredelsen er utpreget østlig (Edwards 2002).

Den begrensede motivvariasjonen på vikingtidens doppsko tyder på at de symboliserte noe bestemt. Paulsen mente at de representerte forskjellige deler av en militærorganisasjon 


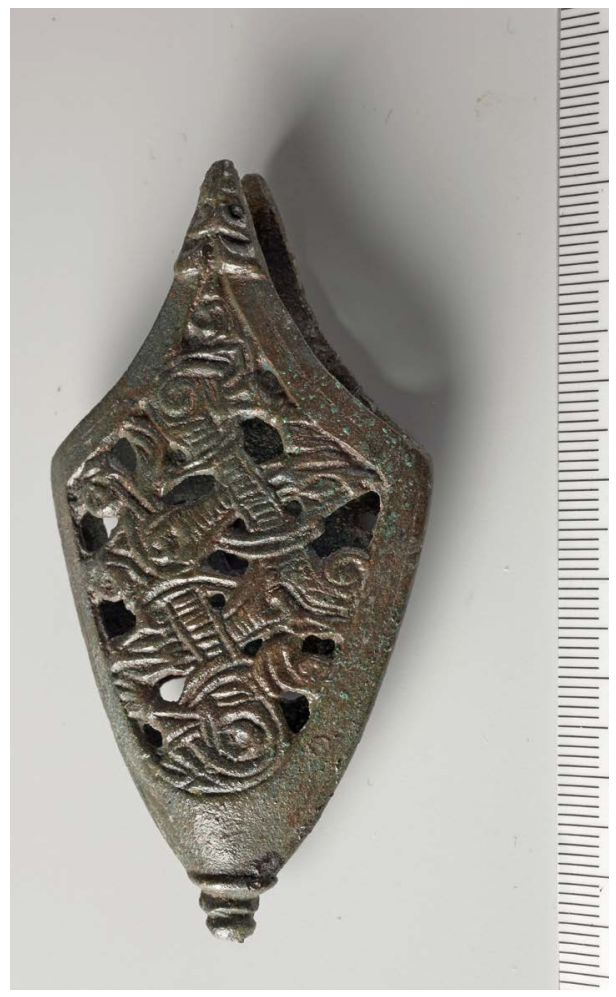

ven fra vikingtiden i Norge - bare «overgått» av skipsgravene i Vestfold, på Karmøy og i Nordfjord (Stylegar 2004).

Gravhaugen, den særpregede gravskikken, hestene, sleden og det komplette våpenutstyret peker ut Gjermundbufunnet som et gravfunn utenom det vanlige. Her møtes hjemlige tradisjoner og velprøvde strategier for å vise kontinuitet med fortidige maktuttrykk på den ene siden, på den andre det internasjonale fenomenet med rikt utstyrte ryttergraver, ofte med praktfulle våpen, som forekommer over store deler av Europa i områder der kristen gravleggingstradisjon ikke var enerådende på det sene 900-tallet (jf. Bíró 2012:18). I tilfellet Gjermundbu har denne miksen dessuten et tydelig østlig preg, med koblinger til svealandskapene og områder enda lenger øst. Enkelte trekk ved gravskikken, som sleden, tyder på at Gjermundbu-mannen (eller de som organiserte begravelsen) ved selvsyn kan ha erfart hvordan fyrstelige begravelser ble gjennomført i østerled.

Den gravlagte var en «langt over gjennomsnittet bevæpnet rytter» som hadde «tilegnet seg fremmede impulser», kanskje gjennom egen tilstedeværelse langt borte, og må ha vært en «betydningsfull person» på Opplandene, oppsummerer Torsten Capelle (Capelle 1998). For Grieg var den gravlagte en småkonge. Han gjetter på én av Snefrid-sønnene: «Sigurd Rise, Halfdan Hålegg, Gudrød Ljome eller Ragnvald Retilbeine, som ifølge Snorre ble tildelt Ringerike, som småkongedømme» (Grieg 1947:70).

Det lar seg neppe gjøre å være så konkret som dette når det gjelder å identifisere rytteren som ble gravlagt i Haugsbygd en gang på slutten av 900-tallet. Men vi mener at det er mulig 
å sirkle inn den historiske konteksten som den døde opererte i, og kan hende i større grad enn det som er tilfellet med mange andre høystatusgraver fra vikingtiden i Norge. Stikkordene er Ringerikes og Opplandenes status innenfor den politiske geografien i Skandinavia på denne tiden, og den spesielle rollen regionen ser ut til å ha spilt som «rekrutteringsmark» for krigstjeneste i austrveg.

Ser vi på sagaer og andre kilder til den politiske geografien i Norge i sen vikingtid, fremstår Trøndelag med Hålogaland og Vestlandet som to separate maktområder med forbindelser vest over havet til De britiske øyer og vesterhavsøyene - de to opptrer tidvis sammen samlet, tidvis hver for seg, og er i perioder formelt under dansk overherredømme. Oslofjordområdet, Viken, er derimot styrt mer direkte av danske underkonger, mens Opplandene har tydelige forbindelser østover (Steen 1929:82). I Odd munks saga om Olav Tryggvason heter det rent ut sagt at innlandsbygdene ikke lå fullstendig under de norske kongene som hersket i kystlandskapene, men at fylkeskongene på Opplandene adlød sveakongen (Soga om Olav Tryggvason, kap. 48, Rindal 1977). Historia Norvegiae nevner «alle småkongene og alle som svarte skatt til sveakongene» (Norges historie, Salvesen 1990:32).

«Småkongene» på Opplandene fremstilles i sagaene som aktive motstandere av det fremvoksende «rikskongedømmet» og av kristningsforsøkene; motstanden mot kristningen gjenspeiles delvis i det arkeologiske materialet, først og fremst gjennom at de tradisjonelle gravskikkene kan følges inn på 1000-tallet (Engelstad 1929; Jacobsen og Larsen 2005; Mikkelsen 2019).

I sagaene fortelles det om mange av disse småkongene, og noen av dem knyttes til Ringerike. Morkinskinna og andre sagaer hevder at Sigurd Syr, Harald Sigurdssons far og etter sagatradisjonen sønnesønns sønn av Harald Hårfagre, var konge på Ringerike (Morkinskinna, kap. 9, Flokenes 2001). Odd munk gjør på sin side Harald Grenske og Tryggve Olavsson, fedre til henholdsvis Olav Haraldsson og Olav Tryggvason, til Ringerikskonger (Soga om Olav Tryggvason, kap. 1, Rindal 1977).

I Ragnarssona Páttr og andre steder møter vi ringerikskongen Sigurd Hjort, som gjennom flere ledd nedstammet fra Ring, som igjen var sønn av Dag. Hversu Noregr byggdist og sagatradisjonen fører slekten tilbake til Halvdan gamle og enda lenger, men også frem til Harald Hårfagre (Korleis Noreg vart bygt, Flokenes 2003). Heimskringla og andre sagaer lar så slekten gå videre fra Harald og frem til småkongen Ring Dagsson og hans sønn, Dag Ringsson (Olav den helliges saga, kap. 199, Hødnebø og Magerøy 1979).

I Páttr Eymundar ok Ólafs konúngs fortelles det om denne Ring Dagsson som rådet over Ringerike (Rafn 1831). Han hadde tre sønner: Dag, Rørek og Eymund. Heimskringla har mye stoff om Dag, som spilte en sentral rolle på Olav Haraldssons side på Stiklestad i 1030, og om farbroren Rørek, som stod i spissen for de opplandske småkongenes motstand mot Olav. Sagatåtten handler imidlertid først og fremst om Eymund, som ifølge tåtten fikk en viktig politisk og militær posisjon i Rusriket etter storfyrst Vladimirs død (1015).

Dag Ringsson er omtalt i et vers av Tormod Kolbrunarskald, og må være en historisk skikkelse. Han vokste opp i Sverige, der hans far skal ha fått et rike, og ble med Olav Haraldsson til storfyrst Jaroslav i Kiev. Etter Olavs død på Stiklestad foreslo han seg selv som konge etter Olav, ettersom han var av kongelig ætt (Legendariske saga, kap. 83, Flokenes 2006). Hvis vi, som Grieg, skal «gjette» på Gjermundbu-mannens bakgrunn, er en person fra Ring Dagssons slekt kan hende det beste forslaget. 
Mens det ofte er den danske eller sørskandinaviske innflytelsen som trekkes frem for Øst-Norges del (Røstad 2012), har Myhre pekt på østlige trekk ved elitegravene ved Oslofjorden fra tidlig 900-tall (Myhre 2015:154). Når det gjelder Opplandene og forbindelsene østover i vikingtid, er disse tydeligere i det arkeologiske materialet der enn i Vestfold. De nære kontaktene til Sveariket er trolig også forbindelsesleddet videre østover, til Rusriket, slik vi ser i Gjermundbufunnet.

Funnets østlige preg, blant annet når det gjelder rytter- og våpenutstyret, bør ha en konkret bakgrunn. Vi mener at den bør søkes i opplendingenes deltagelse i Rusfyrstenes druzhina.

Den yngre innskriften på Alstadsteinen (Toten) er Norges eneste runeinnskrift som minnes en person som døde i Rusriket. Den forteller at Engle reiste steinen etter sin sønn, Torald, som døde mellom Viticev og Ustje, ved Dnjepr sørøst for Kiev (Kleiber 1965, jf. Olsen 1941:156). Alstadsteinen er en bildestein, og ett av motivene (knyttet til den eldre innskriften på steinen) er en «heraldisk» rovfugl med klare referanser til «birka-falken» og rurikidenes merke, og til fuglen på en stor gruppe doppsko fra yngre vikingtid (HedenstiernaJonsson 2009:170). Den eldre, delvis ødelagte innskriften, sier at selve steinen er hentet på Ringerike.

Boris Kleiber setter den yngre innskriften i sammenheng med den nevnte Eymund Ringsson, som sammen med fosterbroren Ragnar ifølge sagaen kom til Holmgard med 700 mann etter Vladimirs død, og var tre år i storfyrst Jaroslav tjeneste, og siden hos Jaroslavs fiender. Han peker også på at innskriften forteller så nøyaktig om Toralds dødssted at både Engle og Torald har hørt til Eymunds følge, og at bare førstnevnte vendte hjem igjen (Kleiber 1965:71-73).

Innskriften er fra 1000-tallet, og det er særlig under storfyrst Jaroslav at vi møter krigere fra Norge i russisk tjeneste. Det er heller ingen tvil om at flere av dem som er nevnt i sagaene - Eymund Ringsson, Olav Haraldsson og Harald Sigurdsson - kan knyttes til Opplandene og Ringerike. Det er grunn til å tro at de representerer en tradisjon som går tilbake til 900-tallet. Russiske kilder forteller at skandinaviske leietropper var involvert da Vladimir kjempet om makten i 980, og kom tilbake med «væringer» etter å ha vært i eksil i Skandinavia («za more») (Lind 2020). Ifølge Odd munks saga og Heimskringla var Sigurd Eiriksson i Vladimirs druzhina på det tidspunktet hans søster Astrid og den unge Olav Tryggvason kom til Novgorod (Rindal 1977; Hødnebø og Magerøy 1979). Olav vokste så opp i kretsen rundt Vladimirs livgarde. Både Historia Norvegiae og Ágrip forutsetter at Sigurd Eiriksson var opplending (Indrebø 1973; Salvesen 1990).

Den gravlagte på Gjermundbu må ha vært en del av den samme østfarer-tradisjonen på Ringerike, og trolig har han hatt en ledende rolle i denne virksomheten, kanskje til og med organisert den. Det tunge rytterutstyret med hjelm og ringbrynje, pil og bue og to (?) sverd er som et ekko av Rusherskernes kamper mot ulike rytterfolk på steppene i sør og øst. Svjatoslav hadde i 960-årene ført felttog mot Khazaria og mot bulgarerne på Balkan, og vært i krig med petsjenegerne (Curta 2019:296). Etter at Vladimir kom til makten i 980, kriget han mot volgabulgarerne i 985, og var stadig i strid med petsjenegerne (Curta 2019:298-300). Rusriket møtte også tungt rytteri fra Bysants på slagmarken, som da Vladimir i 986 og 987 med væringenes hjelp assisterte keiser Basileios 2. med å slå ned et indre opprør (Curta 2019:299). 


\section{Rekonstruksjonen}

I arbeidet med Gjermundbufunnet har vi valgt å lage en «rekonstruksjon» av gravleggingssituasjonen. Formålet med en visuell rekonstruksjon av gravinnholdet er todelt: 1) som formidling av hva gravfunnet representerer, og 2) som metode for å nærme seg en romlig forståelse av hvordan gjenstandene kan ha vært organisert i begravelsessituasjonen. Dette kan igjen avføde nye problemstillinger og tanker om gravens rituelle kontekst. Formidlingsaspektet ved visuelle rekonstruksjoner er også å skape forståelse og interesse for funnet og for arkeologi, ikke minst for publikum utenfor det arkeologiske fagfelleskapet. En visuell rekonstruksjon gir også et godt felles utgangspunkt for faglig diskusjon og andre fortolkninger.

En visuell rekonstruksjon er naturligvis ikke noen definitiv fasit for hvordan gravsituasjonen opprinnelig var, men en fortolkning og ett av flere mulige scenarier ut fra de bevarte sporene. Hvilke ritualer og forestillinger som ligger til grunn for gravens sammensetning og organisering, kan vi bare gjette oss til.

I og med at dette er en kremasjonsgrav hvor gjenstandene og beinmaterialet er samlet sammen og deponert etter selve kremasjonen, har vi få holdepunkter for gjenstandenes distribusjon i forkant av brenningen.

For en visuell 3d-rekonstruksjon må man ta utgangspunkt i de gjenstandene som er bevart/funnet. Det materielle utgangspunktet er kun de delene av de opprinnelige gjenstandene som har overlevd kremasjonsbålet, og som ble deponert i graven. Målet blir i første omgang å gjenskape de delvis fragmenterte bevarte gjenstandene slik de opprinnelig har sett ut. For de organiske delene som ikke lenger er bevart, tas utgangspunkt i tilsvarende eller lignende funn fra samme tidsperiode, i den grad slike finnes. I tillegg legges det til grunn slike ting som at den døde var iført klær, at verktøy og våpen har hatt treskaft, og at

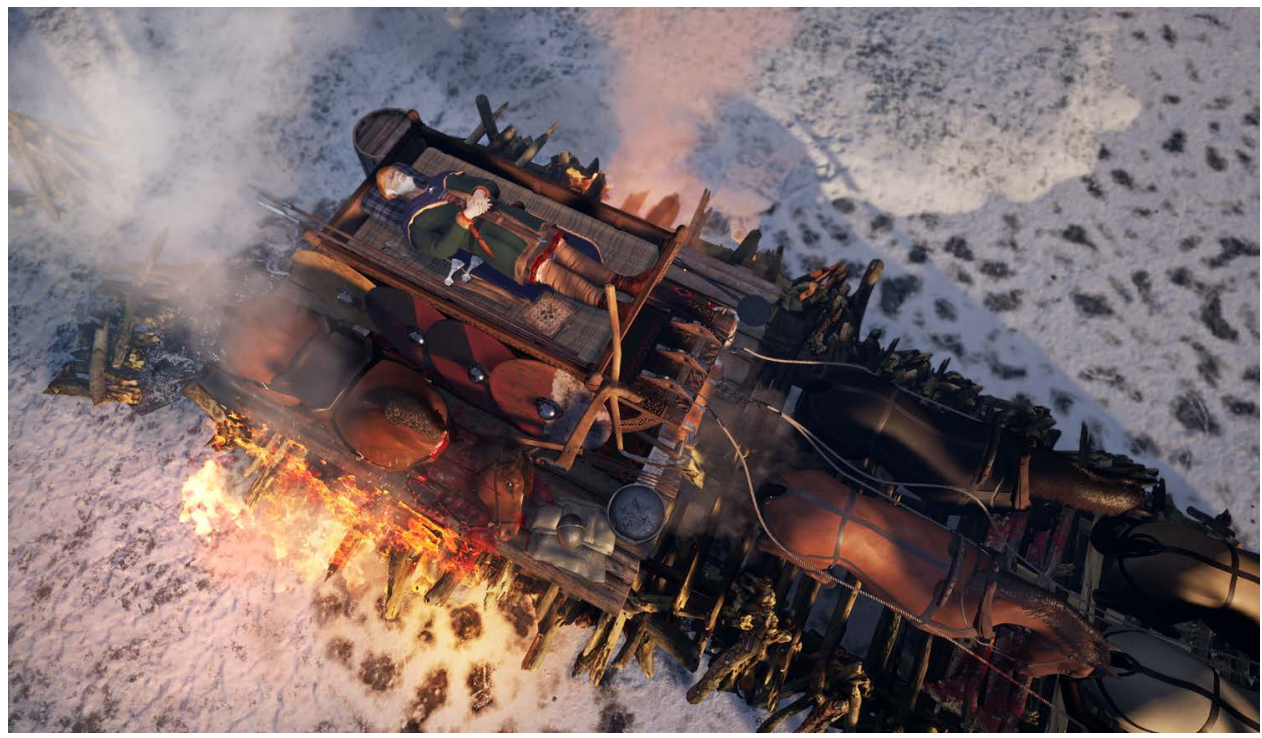

Figur 15. Forslag til rekonstruksjon av likbrenningssituasjonen på Gjermundbu. Illustrasjon: Ragnar L. Børsheim. 
eksempelvis pilspisser i en grav gjør det sannsynlig at det også har vært en bue i graven, trolig også kogger.

Gjenstandenes typer og sammensetning viser at dette er en påkostet høystatusgrav fra sen vikingtid. Det indikerer igjen at den døde trolig har hatt påkostede klær i tråd med årstiden. I rekonstruksjonen er den døde iført vintertøy med pelskant og en østlig inspirert skinnlue. Beinmaterialet i funnet er analysert til å være fra et voksent, kraftig bygd menneske, trolig en mann. Alderen er ukjent, men personen i rekonstruksjonen er middelaldrende/eldre, i tråd med at det gjerne tar tid å opparbeide seg makt og status, samt at sannsynligheten for at en eldre person dør, generelt er høyere enn for en yngre.

Brynjen ble funnet foldet sammen på toppen av kjelen i graven, og det er derfor nærliggende å tro at den også var foldet sammen på likbålet. Brynjen er derfor plassert sammen med hjelmen som del av gravgodset og ikke på den døde. Sverdet er av Petersens S-type og forholdvis godt bevart, så sverdet i rekonstruksjonen er modellert etter dette og med dekor på hjalt og knapp. Doppskoen av bronse er også godt bevart, og viser at sverdet i graven har hatt slire, men det øvrige av slirens utforming vet vi ikke noe om. Det er rimelig å anta at sliren var trukket med skinn. Øksene av Petersens typer 40 og 41 er godt bevart, og er gitt enkle treskaft. Saksen og ildstålet er rekonstruert 1 til 1 ut fra funnfoto. For skjoldenes utforming ut over selve skjoldbulene er den basert på skjoldene fra Gokstadfunnet, dvs. treskjold på ca. $90 \mathrm{~cm}$ i diameter, trolig trukket med skinn.

Spillebrikkene og terningene i funnet tyder på at det også har vært et spillebrett med i graven. Her har vi valgt å ta utgangspunkt i et bevart spillebrett fra Irland (Ballinderry), som er fra samme tid og også trolig av samme type som i funnet fra Birka (Arbman 1940, Tafel 146).

Det såkalte «Birkaskrinet» er også utgangspunkt for rekonstruksjonen av skrinet ut fra skrinbeslagene i funnet (Arbman 1940, Tafeln 263/264). Vi har gitt celten, plogen og spydene enkle treskaft. Som nevnt tyder bunten med pilspisser på at det har vært en bue med i graven. Vi har valgt å ikke legge pilene i kogger, for å holde dem synlige. Stekepannen er av typen R430 og nokså godt bevart i funnet, så formen på den er gitt. Hovbeslag/isbrodd og to sporer, samt «brannføtter» til kjelen er ikke tatt med, da de uansett ikke ville være synlige på rekonstruksjonen. For den klinkede jernkjelen er det tatt utgangspunkt i formen til den lignende, R731. Den tilhørende skjerdingen/opphenget er i rekonstruksjonen plassert oppi kjelen.

En sentral del av graven er sledekrokene og hesteutstyr som tyder på en slede i graven. Som forelegg for formen har vi i hovedtrekk valgt den såkalte «Sheteligs slede» fra Osebergfunnet. Den geometriske dekoren på sidene av slederammen er imidlertid hentet fra den såkalte «fjerde slede» i Oseberg. Ranglen, type R460, har sannsynligvis tilhørt sleden og er plassert på sleden i tråd med ett av alternativene i Cajsa Lunds arbeid om ranglenes funksjon (Lund 1974). Sleden med den døde og gravgodset er plassert på en enkel treplatting ovenpå kremasjonsveden. Dette er det mest praktiske med tanke på både synlighet og kremeringsbålet.

Det er minst fem munnbitt i funnet, hvorav fire er av type R569, og ett av den sjeldnere type R576. I rekonstruksjonen er dette tolket som at fire av hestene har vært satt opp som trekkdyr for sleden, i en rituell iscenesetting av reisen til det hinsidige. Vi kan tenke oss at den femte hesten, med det finere munnbittet, har vært den dødes personlige ridehest. Stigbøyler og sporer indikerer en ryttergrav med ridehest, og stigbøylene må ha tilhørt en 
sal. Så ridehesten med sal har vi plassert halshugget ved siden av sleden med den døde. De øvrige fire hestene er fremstilt avlivet på samme maner som i Oseberg, med et kraftig hugg i pannen.

Hestebrodder og sledekroker/slede er årsaken til at rekonstruksjonsscenen er satt til vinterstid.

Dette er som sagt ikke noen «fasit» på hvordan begravelsessituasjonen fortonet seg for dem som var til stede, men rekonstruksjonen gir et glimt av hvor storslagent et slikt gravritual må ha vært når en av samfunnets sentrale personer ble gravlagt i vikingtid. Det er også arkeologiens oppgave å prøve å danne seg et mer helhetlig bilde av fortiden ut fra de mangelfulle materielle fragmentene av fortiden vi har å jobbe med. Gjermundbufunnet er også et godt eksempel på hvor mye informasjon en som arkeolog faktisk kan få ut av en brent grav, sekundært deponert, ikke faglig undersøkt og med noe mangelfull dokumentasjon.

\section{Takk}

Forfatterne vil takke Torkild Waagaard, Lise Gjermundbo, Gudmund Bakke og Bjarne Sørensen for hjelp under arbeidet med artikkelen.

\section{Forkortelser}

Ab. = Aarsberetning for Foreningen til Norske Fortidsmindesmerkers Bevaring. Kristiania.

Boh. forn. = Bohuslänska fornsaker frän hednatiden, beskrivna af Oscar Montelius, 1-2. Norstedt, Stockholm

\section{Noter}

1 Artikkelen er et samarbeid mellom Frans-Arne H. Stylegar og Ragnar L. Børsheim. Børsheim har utarbeidet rekonstruksjonen av gravleggingssituasjonen og refleksjonene rundt den, mens Stylegar har beskrevet funnomstendighetene og satt funnet inn i en større, kulturhistorisk kontekst.

2 Hedmark: C34261 Dalsødegården, Vang; C22324 Møystad, Vang; C11317-23 S. Finstad, Romedal; ab. 1879, s. 279 Gaustad, Romedal; Østfold: C15927-28 V. Vister, Tune; C15774-78 S. Hosten, Rakkestad; Ab. 1866, s. 55 N. Gjulem, Rakkestad; C27168 Holøs, Rakkestad; Bohuslän: Boh. forn. nr. 38 N. Görlöf, Skee; Boh. forn. nr. 49 Hogen, Skee; Boh. forn. nr. 75 Skärje, Skee; Boh. forn. nr. 312 Säm, Tanum; Boh. forn. nr. 343 Musland, Naverstad; Boh. forn. nr. 474 S. Foss, Foss.

3 Det kan være grunn til å stille spørsmål ved den gjengse oppfatningen at runde hjelmer som i Gjermundbufunnet ikke var særlig utbredt i vikingtiden. For Rusrikets del ville det være naturlig å tenke seg påvirkning fra Bysants når det gjelder krigføring, som én forklaring på at hjelmer (og brynjer) forekommer langt oftere der enn $\mathrm{i}$ Skandinavia. En viktig kilde til hjelmtyper i Bysants er manuskriptet Skylitzes Matritensis fra 1100-tallet, et illustrert bysantinsk manuskript som beror i det spanske nasjonalbiblioteket, og der illustrasjonene kanskje er kopier av eldre fremstillinger (Tselikas 2000, jf. Hoffmeyer 1966). I manuskriptet vises både koniske og runde hjelmer (Dawson 2007:20). 


\section{Litteratur}

Aftenposten

10. april 1943 Gjermundbofunnet i Haugsbygd av helt enestående verdi.

Almgren, Bertil

1946 Om vagnåkarnas färder. Gotländskt arkiv 18:87-95.

Ambrosiani, Björn

2001 The Birka Falcon. I Eastern Connections, excavations in the Black Earth 1990 - 1995. 1. The

Falcon Motif, redigert av Björn Ambrosiani, s. 11-27. Birka Studies 5. Riksantikvarieämbetet, Stockholm.

Ambrosiani, Sune

1918 Slädens användning vid dödsriter. Rig 4:204-208.

Andersen, Even Ballangrud

2004 Vikingtidens sverdtyper. Deres sosiale og symbolske betydning. Hovedoppgave i arkeologi, Universitetet i Oslo.

Androshchuck, Fedir

2005 En man i Osebergsgraven? Fornvännen 100:115-128.

2014 Viking swords. Swords and Social Aspects of Weaponry in Viking Age Societies. Statens historiska museum, Stockholm.

Androshchuk, Fedir og Volodymyr Zotsenko

2012 Scandinavian Antiquities of Southern Rus'. A Catalogue. ACHCByz, Paris.

Arbman, Holger

1940 Birka I. Die Gräber. Tafeln. Almqvist \& Wiksell, Uppsala.

Arwidsson, Greta

1977 Die Gräberfunde von Valsgärde 3, Valsgärde 7. Universitetets Museum for Nordiska Fornsaker, Uppsala.

Bakay, Kornél

1967 Archäologische Studien zur Frage der ungarischen Staatsgründung. Acta Archaeologica Academiae Scientiarum Hungaricae 19:105-173.

Bakke, Gudmund

1995 Haugsbygdas eldste historie. Ringerike 1995:47-49.

1997 Bølgen gård - en storgård på Ringerike. Ringerike 1997:25-31.

Barndon, Randi og Asle Bruen Olsen

2018 En grav med smedverktøy fra tidlig vikingtid på Nordheim i Sogndal. En analyse av gravgods, handlingsrekker og symbolikk. Viking 81:63-88.

Berg, Gösta

1935 Sledges and wheeled vehicles. Ethnological studies from the view-point of Sweden. Almqvist and Wiksell, Uppsala.

Bíró, Ádam

2012 Dating (with) weapon burials and the «Waffenwechsel». A preliminary report on new investigations of the so-called Viking-Age swords in the Carpathian Basin from a chronological point of view. I Die Archäologie der frühen Ungarn. Chronologie, Technologie und Methodik, redigert av Tobias Bendeguz s. 191-218. Verlag des Römisch-Germanischen Zentralmuseums, Mainz.

Bjørgo, Tore, Tron Linge, Øystein Skår, Solveig Lohne Rongved og Tore Slinning

2016 Fragments of a Late Iron Age Sledge Melted Out of the Vossaskavlen Snowdrift Glacier in Western Norway. Journal of Glacial Archaeology 2.1:73-81.

Blindheim, Charlotte

1963 Smedgraven fra Bygland i Morgedal. Viking 26:25-80.

1985 De fem lange år på Universitetets Oldsaksamling. Viking 48:27-43. 
Blindheim, Charlotte, Birgit Heyerdahl-Larsen og Anne Stine Ingstad

1999 Kaupangfunnene II. Gravplassene i Bikjholbergene/Lamøya. Undersøkelsene 1950-1957. Del B. Oldsaksformer. Kulturhistorisk tilbakeblikk. Del C. Tekstilene. Universitetets kulturhistoriske museer - Oldsaksamlingen, Oslo.

Braathen, Helge

1989 Ryttergraver. Politiske strukturer i eldre rikssamlingstid. Varia 19. Universitetets Oldsaksamling, Oslo.

Brøgger, Anton Waldemar

1937 Gullalder. Viking 1:137-195.

1943 (Anmeldelse og anmodning om etterforskning), brev sendt politimesteren i Ringerike 4. mai 1943. Top. ark., Universitetets Oldsaksamling, Oslo.

Capelle, Torsten

1998 Gjermundbu. Reallexikon der Germanischen Altertumskunde 12, s. 126-128. De Gruyter, Berlin.

Caple, Chris

2020 The Yarm Helmet. Medieval Archaeology 64:1-64. doi:10.1080/00766097.2020.1755126

Curta, Florin

2019 Eastern Europe in the Middle Ages (500-1300). Brill, Leiden.

Dawson, Tim

2007 Byzantine Infantryman. Eastern Roman Empire c.900-1204. Osprey Publishing, Oxford.

Duczko, Wladyslaw

2004 Viking Rus: Studies on the Presence of Scandinavians in Eastern Europe. Brill, Leiden.

Edwards. Benjamin James Nicholas

2002 A Viking Scabbard Chape from Chatburn, Lancashire. Antiquaries Journal 82:321-328.

Engelstad, Eivind Stenersen

1929 Hedenskap og kristendom II. Trekk av vikingetidens kultur i Østnorge. Universitetets

Oldsaksamlings Skrifter II, s. 313-382. Universitetets Oldsaksamling, Oslo.

Farbregd, Oddmunn

1988 Kvinneliv i vikingtiden. Kven var kvinnene som ligg i langhaugar? K.A.N. 7:3-23.

Flokenes, Kåre (red.)

2001 Morkinskinna. Erling Skjalgssonselskapet, Hafrsfjord.

2003 Den lengste soga om Olav Tryggvason III. Dreyer, Stavanger.

2006 Den legendariske Olavssoga. Dreyer, Stavanger.

Geibig, Alfred

1989 Zur Formenvielfalt der Schwerter und Schwertfragmente von Haithabu. Offa 46:223-267.

Gjerpe, Lars Erik

2005 Gravfeltet på Gulli. Varia 60. Universitetets Oldsaksamling, Oslo.

Grieg, Sigurd

1947 Gjermundbufunnet. En høvdingegrav fra 900-tallet fra Ringerike. Norske Oldfunn VII.

Universitetets Oldsaksamling, Oslo.

Gräslund, Anne-Sofie

1980 Birka IV. The Burial Customs: a study of the graves on Björkö. Kungl. Vitterhetsakademien, Stockholm.

Grylling, Gudbrand

1943 Rapport til herr politimesteren i Ringerike vedk. funnet av en samling oldsaker på Gjermundbo gård i Haugsbygd. Top. ark., Universitetets Oldsaksamling, Oslo.

Guldal, Jon

1933 Gjermundbo i Haugsbygd. Ringerikes Blad, 30. mars 1933.

1936 Gjermundbo i Haug. Litt av gårdens historie. Ringerikes Blad, 15. mai 1936.

1943 Nye gravfunn på Gjermundbo. Ringerikes Blad, 18. mai 1943.

1953 Bli med til Ringerike! Ringerikes Blad, 14. april 1953.

1955 Den gyldne rings bygder og garder. Ringerike 1955:29-30. 
Gustafson, Lil

2016 Møter på Veien - kultplass gjennom 1500 år. Et maktsentr på Ringerike i eldre jernalder.

Kulturhistorisk museum, Oslo.

Gustafsson, Ny Björn

2013 Casting Identities in Central Seclusion. Aspects of non-ferrous metalworking and society on Gotland in the Early Medieval Period. Stockholm University, Stockholm.

Hagen, Anders

1997 Gåten om kong Raknes grav. Hovedtrekk i norsk arkeologi. Cappelen, Oslo.

Halvorsen, Eyvind Fjeld

1955 Det offentlige godset på Ringerike før reformasjonen. Ringerike 1955:20-27.

Hedenstierna-Jonson, Charlotte

2002 A group of Viking Age sword chapes reflecting the political geography of the time. Journal of Nordic Archaeological Science 13:103-112.

2009 Rus', Varangians and Birka Warriors. I The Martial Society. Aspects of warriors, fortifications and social change in Scandinavia, redigert av Lena Holmquist Olausson og Michael Olausson, s. 159-178. Archaeological Research Laboratory, Stockholm University, Stockholm.

Henriksen, Mogens Bo

2016 Brændt, men ikke altid begravet? Vikingetidens ligbrændingssteder og brandgrave. I Død og begravet $-i$ vikingetiden, redigert av Jens Ulriksen og Henriette Lyngstrøm, s. 1-12. Københavns Universitet, København.

Hoffmeyer, Ada Bruhn

1966 Military Equipment in the Byzantine Manuscript of Scylitzes in Biblioteca Nacional de Madrid. Gladius V:1-194.

Holck, Per

1986 Cremated Bones. A Medical-anthropological Study of an Archaeological Material on Cremation Burials. Anatomisk institutt, Universitetet i Oslo, Oslo.

Hougen, Bjørn

1951 Universitetets Oldsaksamlings årsberetning 1943-1950. 1. Oldsaksamlingen i okkupasjonstiden. Universitetets Oldsaksamlings årbok 1949-50, s. 177-180. Universitetets Oldsaksamling, Oslo.

Hødnebø, Finn og Hallvard Magerøy (red.)

1979 Snorres kongesagaer. Gyldendal, Oslo.

Indrebø, Gustav

1973 [1936] A Arrip or Noregs kongesoger. Samlaget, Oslo.

Ivakin, Vsevolod

2012 Burial grounds and graves in medieval Kiev (9th to 13th century). I Rome, Constantinople and Newly-Converted Europe: archaeological and historical evidence I, redigert av Maciej Salamon, Marcin Wołoszyn, Alexander Musin og Perica Špehar, s. 625-638. Leipziger Universitätsverlag - Instytut Archeologii i Etnologii Polskiej Akademii Nauk - Instytut Archeologii Uniwersytetu

Rzeszowskiego, Kraków - Leipzig - Rzeszów - Warszawa.

Jacobsen, Harald og Jan Henning Larsen

2005 Hundorp og Gudbrandsættens maktsymboler. I Hundorp. Tusenårsstaden i Oppland, redigert av Arnfinn Engen, s. 14-51. Samlaget, Oslo.

Kirpichnikov, Anatolij N.

1971 Drevnerusskoe Oruzhie III: Dospech, Kompleks Boevych Sredstv IX-XIII vv. Nauka, Moskva.

Kjellmark.Knut

1905 Ett graffält från den yngre järnåldern i Ås i Jämtland. Ymer 25:351-371.

1939 Kring en gravplan: något om gravskicket i Jämtland under vikingatiden. Fornvännen 35:35-44.

Kleiber, Boris

1965 Alstadsteinen i lyset av nye utgravninger ved Kiev. Viking 29:61-76. 
Kotowicz, Piotr, Jolanta Bagińska, Paweł Kucypera og Krzysztof Rybka

2013 Sword fragment from Nowosiółki Kardynalskie, Tomaszów Lubelski District. Materials and Conservation Remarks. I Weapons Bring Peace? Warfare in Medieval and Early Modern Europe, redigert av Lech Marek, s. 31-40. University of Wrocław, Wrocław.

Kulakow, Wladimir I.

1985 Kultsymbole und Kriegerembleme aus dem Baltikum, aus Skandinavien und Osteuropa im 10. und 11. Jahrhundert. Zeitschrift für Archäologie des Mittelalters 13:53-64.

Lind, John $\mathrm{H}$.

2020 Nordic and eastern elites. Contacts across the Baltic sea: An exiled clan. I Nordic Elites in Transformation, c. 1050-1250, II: Social Networks, redigert av Kim Esmark, Lars Hermanson og Hans Jacob Orning, s. 104-124. Routledge, New York.

Lindqvist, Sune

1921 Ynglingaättens gravskick. Fornvännen 16:83-194.

Ljungkvist, John

2008 Valsgärde - development and change of a burial ground over 1300 years. I Valsgärde studies: The Place and its People, Past and Present, redigert av Svante Norr, s. 13-55. Uppsala universitet, Uppsala.

Liwoch, Radoslaw og Michael Müller-Wille

2012 «Druzhina» graves dating to the time around AD 1000 in Pìdgìrcì (western Ukraine). Archäologisches Korrespondenzblatt 42:421-438.

Lund, Cajsa

1974 Paa rangel 1974. Studier över rangler, föremål av järn från yngre norsk järnålder. Stavanger museums årbok 84:45-120.

Lunde, Peter

1969 Folkeminne frå Søgne. Universitetsforlaget, Oslo.

Løken, Trond

1987 The correlation between the shape of grave monuments and sex in the iron age, based on material from Østfold and Vestfold. I Were they all men? An examination of sex roles in prehistoric society: acts from a workshop held at Utstein kloster, Rogaland 2.-4. november 1979, redigert av Reidar Bertelsen, Arnvid Lillehammer og Jenny-Rita Næss, s. 53-64. Arkeologisk museum i Stavanger, Stavanger

Marek. Lech

2005 Early Medieval Swords from Central and Eastern Europe. Dilemmas of an Archaeologist and a Student of Arms. University of Wroclaw, Wroclaw.

Marstrander, Sverre

1943a Innberetning om undersøkelse av gravfunn på Gjermundbo (gnr. 105 brnr. 1) Haug s., Norderhov pgd., Buskerud, foretatt 2/4 1943. Top. ark., Universitetets Oldsaksamling, Oslo.

1943b Brev fra Oldsaksamlingen v./S. Marstrander til Lars Gjermundbo, 12. april 1943. Top. ark., Universitetets Oldsaksamling, Oslo.

1943c Innberetning om ny undersøkelse av gravhaug på Gjermundbo (gnr. 105, brnr. 1), Haug s., Norderhov pgd., Buskerud, foretatt 14. mai 1943. Top. ark., Universitetets Oldsaksamling, Oslo.

1986 De skjulte skipene. Tuneskipet, Gokstadskipet og Osebergskipet. Gyldendal, Oslo.

Martens, Irmelin

2002 Smeden og hans produkter i norsk vikingtid. I UKM - en mangfoldig forskningsinstitusjon, redigert av Ellen Høigård Hofseth, s. 173-185. Universitetets kulturhistoriske museum, Oslo.

Mikhailov, Kirill A.

2005 A Scandinavian cemetery at Plakun (notes on its geography and topography). Russian History 32:419-432.

Mikkelsen, Egil

2019 Looting or Missioning: Insular and Continental Sacred Objects in Viking Age Contexts in Norway. Oxbow Books, Oxford. 
Müller-Wille, Michael

1971 Pferdegrab und Pferdeopfer im frühen Mittelalter. Berichten van de Rijksdienst voor het Oudheidkundig Bodemonderzoek 20/21:199-248.

1972 Zwei wikingerzeitliche Prachtschwerter aus der Umgebung von Haithabu. Offa 29:50-112.

1998 Zwei Grabfunde des 10. Jahrhunderts in europäischer Perspektive. Rösta (Grab IV) im nördlichen Schweden und Gnezdovo (Grab DN-4) im westlichen Russland. I Zwischen Christianisierung und Europäisierung. Beiträge zur Geschichte Osteuropas in Mittelalter und früher Neuzeit. Festschrift für Peter Nitsche zum 65. Geburtstag, redigert av Eckhard Hübner, Ekkehard Klug og Jan Kusber, s. 51-68. Franz Steiner Verlag, Stuttgart.

Munksgaard, Elisabeth

1984 A Viking Age Smith, his Tools and his Stock-in-trade. Offa 41:85-89.

Myhre, Bjørn

1992 Borre - et merovingertidssenter i Norge». I Økonomiske og politiske sentra i Norden, ca 400-1000 e.Kr. Akerseminaret, Hamar 1990, redigert av Egil Mikkelsen og Jan Henning Larsen, s. 155-179. Universitetets oldsaksamling, Oslo.

2015 Før Viken ble Norge. Borregravfeltet som religiøs og politisk arena. Vestfold fylkeskommune, Tønsberg.

Nicolaysen, Nicolay

1866 Norske fornlevninger. En oplysende fortegnelse over Norges fortidslevninger, celdre en reformationen og henførte til hver sit sted. Foreningen til norske Fortidsminnesmerkers Bevaring, Kristiania.

Nordahl, Else

2018 Valsgärde 14. Uppsala universitet, Uppsala.

Nordkild, Torgeir

2020 Landskapet, døden og etterlivet. Ting å fortelle om gravene langs Beisfjord. Masteroppgave i arkeologi. Norges arktiske universitet, Tromsø.

Olsen, Magnus

1941 Norges innskrifter med de yngre runer 1. Norsk historisk kjeldeskrift-institutt, Oslo.

Paulsen, Peter

1953 Schwertortbänder der Wikingerzeit. Ein Beitrag zur Frühgeschichte Osteuropas. W. Kohlhammer, Stuttgart.

Pedersen, Anne

2006 Ancient mounds for new graves - an aspect of Viking-age burial customs in southern Scandinavia. I Old Norse religion in long-term perspectives. Origins, changes, and interactions, redigert av Anders Andrén, Kristina Jennbert og Catharina Raudvere, s. 346-353. Nordic Academic Press, Lund.

Petersen, Jan

1919 De norske vikingesverd. En typologisk-kronologisk studie over vikingetidens vaaben. Dybwad, Kristiania.

1951 Vikingetidens redskaper. Dybwad, Oslo.

Rafn, Carl Christian (red.)

1831 Oldnordiske sagaer 5. Kongelige Nordiske Oldskriftselskab, København.

Rindal, Magnus (red.)

1977 Soga om Olav Tryggvason etter Odd munk Snorreson. Samlaget, Oslo.

Ringerikes Blad

31. mars 1943 Stort oldtidsfund i Haugsbygd. En innholdsrik gammel gravhaug på Gjermundbo.

2. april 1943 Oldfunnet på Gjermundbo i Haugsbygd. Det skriver seg antagelig fra vikingtiden.

3. april 1943 De sakkyndige begeistret for gravfunnet i Haugsbygd. «Gjermundbo-høvdingen» ble gravlagt omkring år 900.

13. april 1943 Gjermundbofunnet i Haugsbygd av helt enestående verdi. Høvdinggrav fra slutten av 900-årene. Den første hjelm og den første brynje fra vikingetiden som er funnet i Norge. 
Røstad, Inger Marie

2012 En fremmed fugl: «Danske» smykker og forbindelser på Østlandet i overgangen mellom vikingtid og middelalder. Viking 75:181-210.

Salvesen, Astrid (red.)

1990 Norges historie. Norges historie. Historien om de gamle norske kongene/Theodricus munk. Historien om danenes ferd til Jerusalem. Aschehoug, Oslo.

Schulze-Dörrlamm, Mechthild

2012 Schwerter des 10. Jahrhunderts als Herrschaftszeichen der Ottonen. Jahrbuch des RömischGermanischen Zentralmuseums 59:609-651. Verlag des Römisch-Germanischen Zentralmuseums, Mainz.

Sedov, Valentin V.

1982 Vostočnye slavjane v VI-XIII vv. Nauka, Moskva.

Shenk, Peter

2002 To Valhalla by horseback? Horse burial in Scandinavia during the Viking Age. Masteroppgave, Universitetet i Oslo.

Shetelig, Haakon

1912 Vestlandske graver fra jernalderen. Grieg, Bergen.

Sikora, Przemyslaw

2003 Frühmittelalterliche Ortbänder bei West- und Ostslawen. Zeitschrift für Archäologie des Mittelalters 31:11-38.

2013 Die Ortbänder aus Hafurbjarnarstaðir und Ljárskógar - Zwei besondere Fundstücke aus Island. Bemerkungen zur ihren Datierung und Bedeutung. Kulturwandel im Spannungsfeld von Tradition und Innovation. Festschrift für Michael Müller-Wille, redigert av Sunhild Kleingärtner, Ulrich Müller og Jonathan Scheschkewitz, s. 361-372. Wachholz, Neumünster.

Sindbæk, Søren Michael

2003 Varægiske vinterruter. Slædetransport i Rusland og spørgsmålet om den tidlige vikingetids orientalske import i Nordeuropa. Fornvännen 98:179-193.

Skre, Dagfinn

1997 Raknehaugen. En empirisk loftsrydding. Viking 60:7-42.

1998 Herredømmet. Bosetning og besittelse på Romerike 200-1350 e.Kr. Universitetet i Oslo, Oslo.

Skøien, Johan

1943 Brev fra J. Skøien til Oldsaksamlingen, 1. mai 1943. Top. ark., Universitetets Oldsaksamling, Oslo.

Slomann, Wencke

1959 Scetrangfunnet. Hjemlig tradisjon og fremmede innslag. Norske oldfunn IX. Universitetets Oldsaksamling, Oslo.

Slåtto, Torbjørn

1979 Gårdsvald - eiendomsfigurer. Ringerike 1979:23-28.

Solberg, Bergljot

1984 Norwegian spear-heads from the Merovingian and Viking periods. Universitetet i Bergen, Bergen.

Steen, Sverre

1929 Ferd og fest. Reiseliv i norsk sagatid og middelalder. Oslo: Aschehoug.

Steuer, Heiko

1970 Phasen der Bewaffnung nach Aussagen der archäologischen Quellen Mittel- und Nord-Europas im ersten Jahrtausend n. Chr. Frühmittelalterliche Studien 4:348-383.

Stjerna, Niklas

2004 En stäppnomadisk rustning från Birka. Fornvännen 99:27-32.

Stolpe, Hjalmar

1912 Graffältet vid Vendel. Kungl. Vitterhetsakademien, Stockholm. 
Storaker, Johannes

1938 Mennesket og arbeidet $i$ den norske folketro. Norsk folkeminnelag, Oslo.

Stylegar, Frans-Arne Hedlund

1997 Hedeby - Lindesnes. Tanker rundt et gammelt myntfunn fra Spangereid, Lindesnes kommune, Vest-Agder fylke. Universitetets Oldsaksamlings årbok 1995/1996, s. 115-120. Universitetets Oldsaksamling, Oslo.

2004 Mellom stein og Gjermundbu: Makt og bebyggelse på Ringerike i vikingtid og middelalder. I Halvdanshaugen - arkeologi, historie og naturvitenskap, redigert av Jan Henning Larsen og Perry Rolfsen, s. 154-182. UKM Skrifter nr. 3. Universitetets kulturhistoriske museer, Oslo.

2014 Byggland i Morgedal - smedgrav, eller? Fornvännen 109:90-100.

2021 De norske skipsgravene, nye og gamle. I Glimt fra vikingetiden. Danske Amatørarkceologer 30 år, redigert av Iben Skibsted Klæsøe, Jeppe Boel Jepsen, Freddy Arntsen, Benny Staal, Alan Tomlinson, Suzanne Barry, Niels Bødker Thomsen og Severin Tobias Mortensen, s. 43-51. Danske Amatørarkæologer, København.

Svane, Gunnar Olaf (red.)

1983 Nestors krønike. Beretningen om de svundne år. Wormianum, Aarhus.

Szameit, Erik

2001 Fränkische Reiter des 10. Jahrhunderts. I Otto der Große. Magdeburg und Europa. Katalog zur Ausstellung 2, redigert av Mathias Puhle, s. 254-261. Philipp von Zabern Verlag, Mainz.

Tselikas, Agamemnon (red.)

2000 Joannis Scylitzae, Synopsis: Historiarum: incipiens a Nicephori imperatoris a genicis obitu ad Isacii Comneni imperium. Militos, Athen.

Ulriksen, Jens

2011 Vikingetidens gravskik i Danmark. Spor af begravelsesritualer i jordfæstegrave. Kuml 2011:161245.

Vedeler, Marianne

2019 Oseberg. De gåtefulle billedvevene. Scandinavian Academic Press, Oslo.

Vestergaard, Felix

2007 Monumentale skibssætninger i Danmark og Skåne. Kuml 2007:145-190.

Vike, Vegard

2000 Brynjevev. Metallografisk analyse av brynjemateriale ved Oldsaksamlingen i Oslo. Semesteroppgave, Avd. for konserveringsstudier, Universitetet i Oslo.

Vlasatý, Tomaš

2015 Saxy a bojové nože z východní Evropy. Projekt Forlog: Reenactment a věda [online]. https:// sagy.vikingove.cz/saxy-a-bojove-noze-z-vychodni-evropy/.

Wadyl, Sławomir (red.)

2019 Ciepte. Elitarna nekropola wczesnośredniowieczna na Pomorzu Wschodnim. Muzeum Archeologiczne w Gdańsku, Gdańsk.

Wegraeus, Erik

1986 Die Pfeilspitzen von Birka. I Birka II. Systematische Analysen der Gräberfunde, redigert av Greta Arwidsson, s. 21-34. Kungl. Vitterhetsakademien, Stockholm.

Wiel, Iver

1933 [1743] Fogd Wiels beskrivelse av Ringerike år 1743. Ringerikes Blad, Hønefoss. 